Historic, archived document

Do not assume content reflects current scientific knowledge, policies, or practices. 


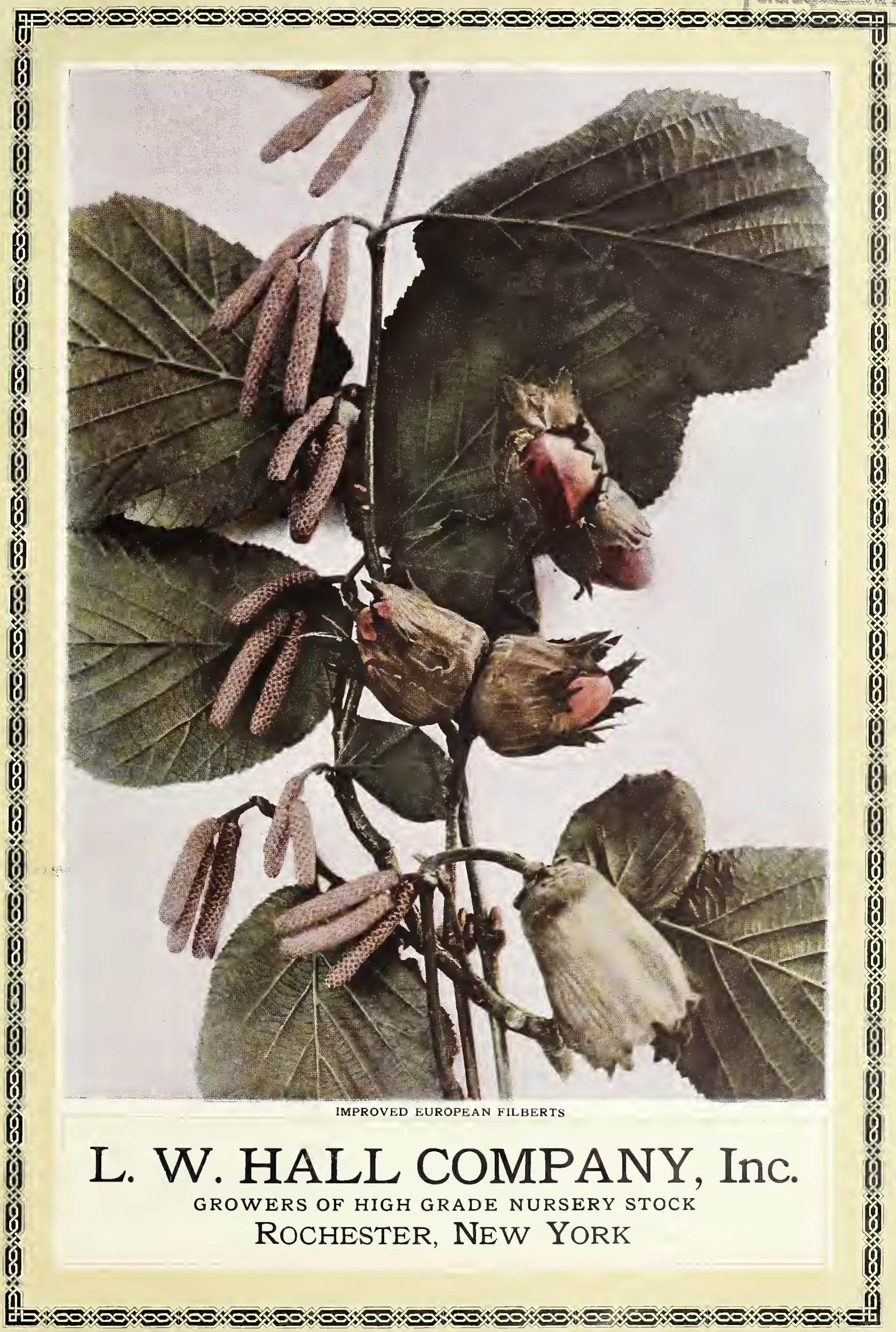




\section{Improved European Filberts}

Handsome Shrubs

$100 \%$ USEFUL

Food Producers

Bear 2 nd or $3 \mathrm{rd}$ year after planting, and at the tenth year yield 20 to $25 \mathrm{lbs}$. per bush.

\section{Improved European Filberts (Hazel Nuts) NOW IS THE TIME TO PLANT THEM}

CULTURE OF FILBERTS.

The improved filberts will thrive anywhere that the native or wild American fibert will grow, which is practically the entire United States. They will grow in practically any soil that is moderately rich and well drained, and require very little cultivation, only sufficient to keep the ground free of grass and weeds. Fertilizer should be used sparingly, except where ground is poor and stony.

When planting, cut back the tops of the bushes about one-half. All filberts are inclined to produce suckers, or young shoots growing up from the roots, during the first few years. These suckers should be removed as soon as they appear. And for commercial orchard plantings the bushes should be pruned to form low-headed trees with trunks ten to fifteen inches high, with all weak and unnecessary wood removed from the center, not merely cut back.

For garden culture, or planted as ornamental shrubs, the plants should be set about six feet apart. For. screen or hedge planting set about four feet apart.

For commercial orchards the improved filberts should be set

HANDSOME AS A SHRUB-COMBINES BEAUTY WITH PROFIT.

In addition to its wonderful nut-bearing qualities (which intwelve feet anart each way, making 300 bushes to the acre. We have produced over two pounds per bush on five-year-old bushes. Suppose we say these bushes will bear one pound per bush in the fifth year. It is estimated they will double in produc tion for five years after, making a minimum production of 32 pounds per bush the tenth year. To be most conservative, figuring 25 pounds per bush at the tenth year. one acre should produce 7,500 pounds" of nuts. "This production, under proper care, will continue indefinitely.

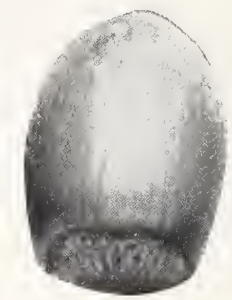

Lancăster, Pa., Sept. 12, 1922

Mighty glad to see the Filbert froposition so prosperous. In my imagination now I can see big Filbert orchards in lork State in the not far distant future.

\section{J. F. JONES, V}

Baldwin, N. Y., Sept. 11, 1922

While the Filberts in the nursery have been grown for propagating new plants rather than for raising nuts, yet the nuts on them this year are sufficient to impress anybody with the possibilities of nut WILLARD G. BIXB' Y, Treas. Northern Nut Growers Association.

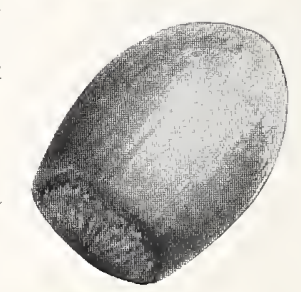

Lockport, N. Y., Sept. 14. 1922. Everyone was much surprised and delighted to note the wonderful progress made in Fibert cule, proving what can be accomplished by anyone wishing to plant these valuable shrubs. A. C. POMEROY

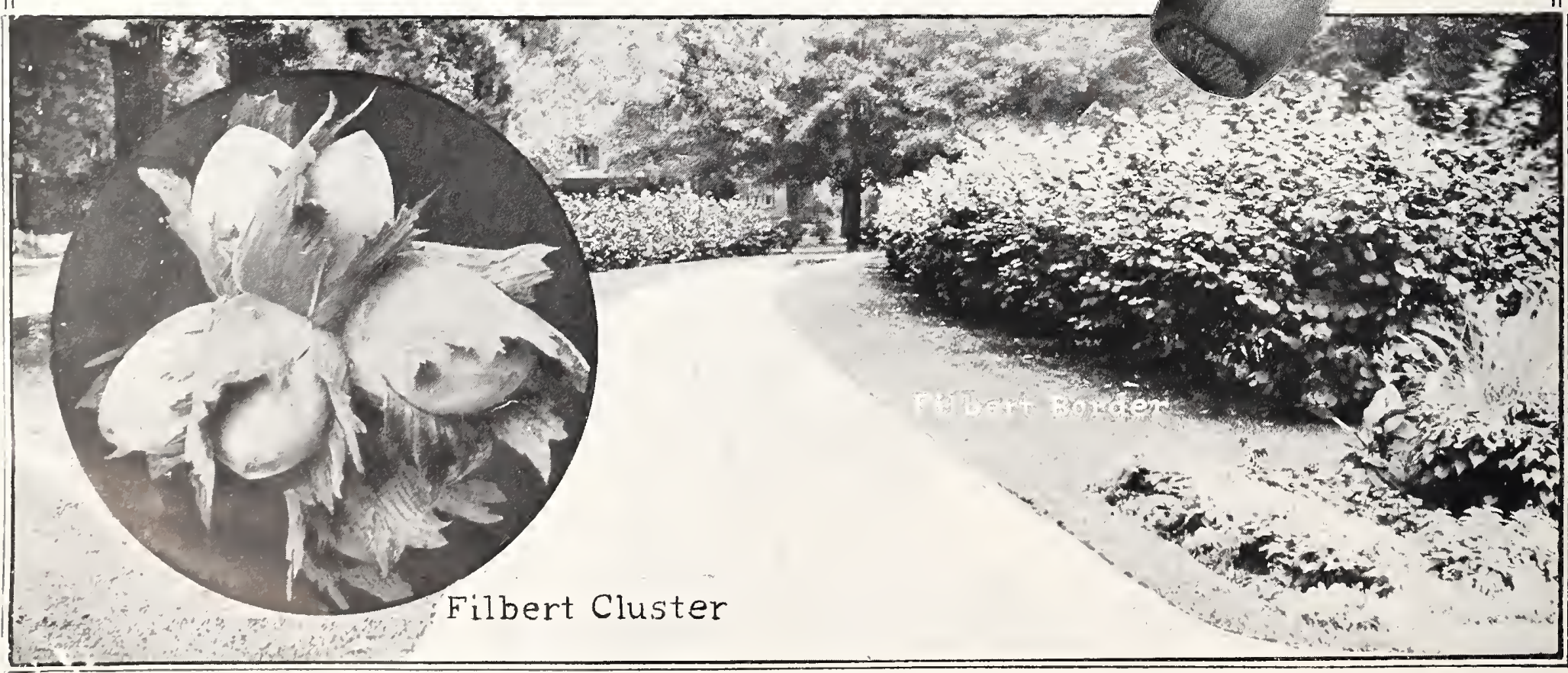




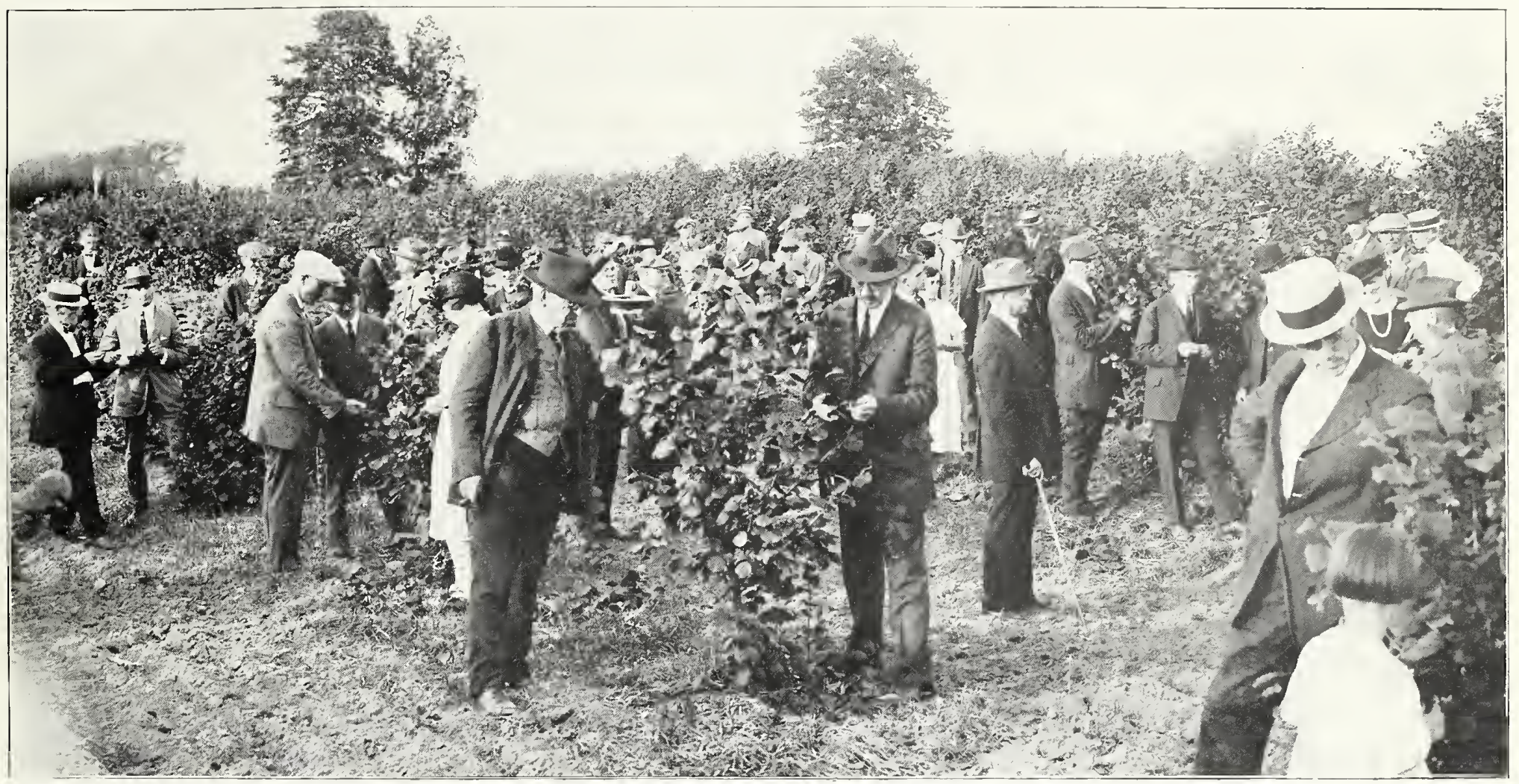

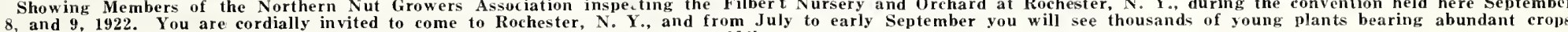
of these wonderful nuts. To anyone interested, we say, "Come and see for yourself."

Of the twenty-one varieties origmally imported in 1912, we have selected eight of the best in habit of growth, hardiness, quality, and productiveness, which we now offer. All are highly desirable sorts that will give satisfaction and produce results

In order to obtain the best results, at least three varieties should be planted, and we advise customers to leave the selection to us, and we will be pleased to select for each order varieties that will give best results and insure proper pollenization for fruting.

Our Improved Filberts are specially valuable because of the very wide range of teritory in which they can be grown. They thrive practically all over the United States, in any ordinary soil, and be cause of their liardiness are adapted to the more Northern parts of fruited.

\section{Budded or Grafted English Walnuts

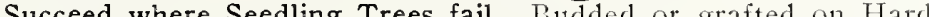
Black Walnut stock. Nore vigorous, hardy in all sections, bear earlier, produce nuts in three to four years that equal the best imported sort in size and quality. Recommended by the American and Northern Nut Growers Associations, and the United States Dept. of Agriculture as the only dependable English Walnuts to plant. We offer two of the best varieties, the Vrooman Franquette and Wiltz Mayette.

VROOMAN FRANQUETTE. Large, oblong; rich, exquisite flavor, a favorite for dessert A popular variety, highly recommended and extensively planted. Tree robust, bears abundantly and regularly. The peer of all the French varieties. 3 to $4 \mathrm{ft}$., $\$ 2.50$ each.

WILTZ MAYETTE. Considered one o the finest that reaches New York markets. where it always brings highest prices Large, smooth, fine appearance, flesh oily. rich, sweet, and very good. Tree strong, vigorous and handsome. 3 to $4 \mathrm{ft}$., $\$ 2.50$ each.

Budded or Grafted Black Walnuts THOMAS. Originated in Pennsylvania, one of the finest and best of all large nuts in cracking qualities. Nut very large, with large kernel, and of very good quality

Tree

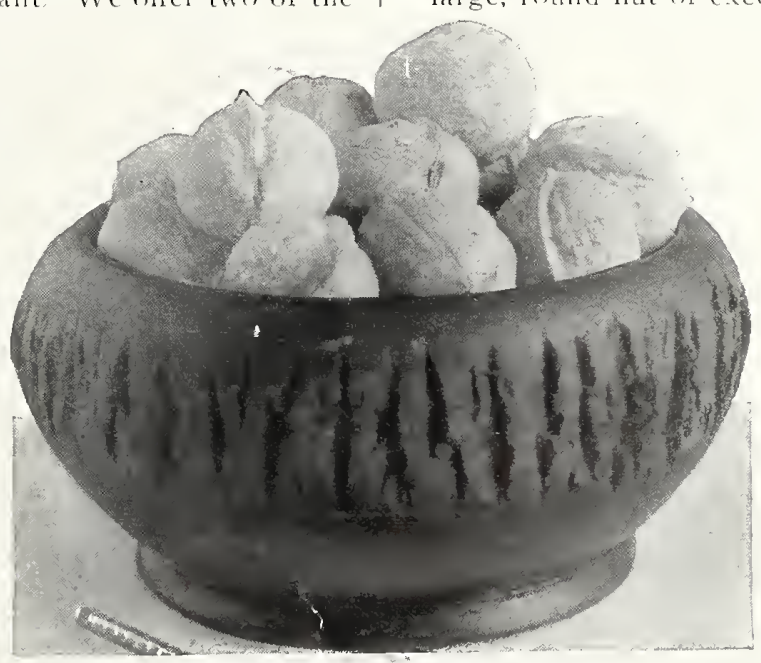

PRICE OF THE IMPROVED EUROPEAN FILBERTS

\begin{tabular}{|c|c|c|}
\hline 18 inch &.$\$ 1.50$ & $\begin{array}{c}\text { Per Ten } \\
\$ 12.50\end{array}$ \\
\hline 2 feet & $\ldots 1.75$ & 15.00 \\
\hline 3 feet & $\ldots \ldots \ldots \ldots \ldots 2.00$ & 17.50 \\
\hline
\end{tabular}

All plants are grown on their own roos and are absolutely true to type. Nuts ripen in September and should not be gathered until thoroughly ripened, the condition indicated by the browning of the liusk

The filbert nursers tration of the possibilities of the filbert in the East. It was a great sight for the members of the Association, long craving for just such a demonstration.

DR W. C. DEMING.
Budded or Grafted Pecans

Berick and Posey. 3 to $4 \mathrm{ft}$., $\$ 2.50$ each.

Indiana, Busseron Seedling Nut Trees

BLACK WALNUT. Most valuable for timber; rapid grower; bears to 6 ft., $\$ 1.50$ each.

ENGLISH WALNUT. Seedling trees, grown from selected nuts. Exceedingly Produce large crops fiuts, but apt to vary in size and quality. 3 to $4 \mathrm{ft}$., $\$ 1.50$ each.

JAPAN WALNUT (Siebnldi) Perfectly hardy, rapid grower: one of the finest or namental trees. Nuts resemble butter nuts, but somewhat smaller, with thinner, smoother shell. Worthy of extensive planting. 3 to $4 \mathrm{ft}, \$ 1.50$ each.

BUTTERNUT. Valuable for timber; bears an oblong. thick-shelled nut of delicious flavor. 5 to $6 \mathrm{ft}$., $\$ 1.50$ each.

\section{Chestnuts}

Because of Federal quarantine laws prode hibiting the shipment of Chestnut trees Wiltz Mayette English Walnuts.

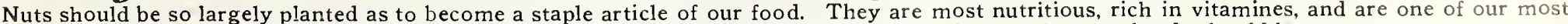
important food products. For use as a luxury alone, thousands of acres of nut orchards should be set out. 


\section{Northern Grown Apples}

The Apple is the first in importance of all fruits. it will thrive on nearly any well drained soil. Its period of ripening, unltke other fruits, extends nearly through the whole year. By making a careful selection, a constant succession can be obtained. For family use there is no fruit that is more indispensable. No other fruit is so healthful. Besides this, and just as important, is the fact that the average price on the market is steadily increasing and the immense demand for home consumption, foreign shipping, canning, and evaporating assures high prices. The aple, if given the same care and attention as other farm crops, will yield greater returns per acre

The following list we consider to be the best for general planting.
Standard Apples and Crabs, grown on Best

Standard Apples and Crabs, grown on Best Imported French Whole Rcot Seedlings, extra strong, selected trees, 2 and 3 year:

5 to 7 feet

4 to 5 feet

\section{Summer Apples}

EARLY HARVEST. Medium to large; pale yellow, fine flavor. Tree moderate, erecí grower; a geod bearer. Middle to end of August.

EARLY CRIMSON BEAUTY. Best early red apple. Gond size, white flesh, tender, juicy, pleasant flavor. Sells better than Astrachan. Very lardy, bears young, very productive.

SWEET BOUGH. One of the finest summer apples. Bears young and abundantly, Fruit is large, pale green: flesh fine, very tender, juicy, sweet, with rich flavor. (August)

ASTRACHAN, RED. Good size, deep crinson over-spread with thick bloom. Flesh tender, juicy and rich; excellent for cooking or dessert. Tree very hardy, vigorous grower, comes into learing while very young. (August.)

YELLOW TRANSPARENT. One of the best extra early apples for all sections. Good size, clear white, turning to pale yellow; flavor acid, very good. Rears very young, yields immense crows every year. Extremely hardy.

\section{Each $\quad 10 \quad 100$ \\ $\$ 1.00 \quad \$ 8.50 \quad \$ 75.00$}

\section{Fall Apples}

DUCHESS OF OLDENBURG. One of the best. Hand some, good size, streaked red and yellow. Excellent quality. Very hardy, bears very young and abundantly. An extra good shipper, one of the best money-makers; one of the most important varieties for all sections.

FAMEUSE (Snow Apple). One of our finest dessert fruits. Medium size, smooth, regular, deep crimson, with snowy white. tender, melt ing- flesh of delightful flavor.

FALL PIPPIN. Very large, yellow, tender, juicy and rich. Tree vigorous.

GRAVENSTEIN. Large, greenish-yellow with red stripes, Juicy, sub-acid, aromatic; very good to best.

MAIDEN BLUSH. Medium to large; pale waxen-yellow with crimson blush. Flesh tender. juicy, sub-acid. Hardy, and a fine grower.

TWENTY-OUNCE. Very large, yellow and red, tender, juicy, cris;, sub-acid; productive.

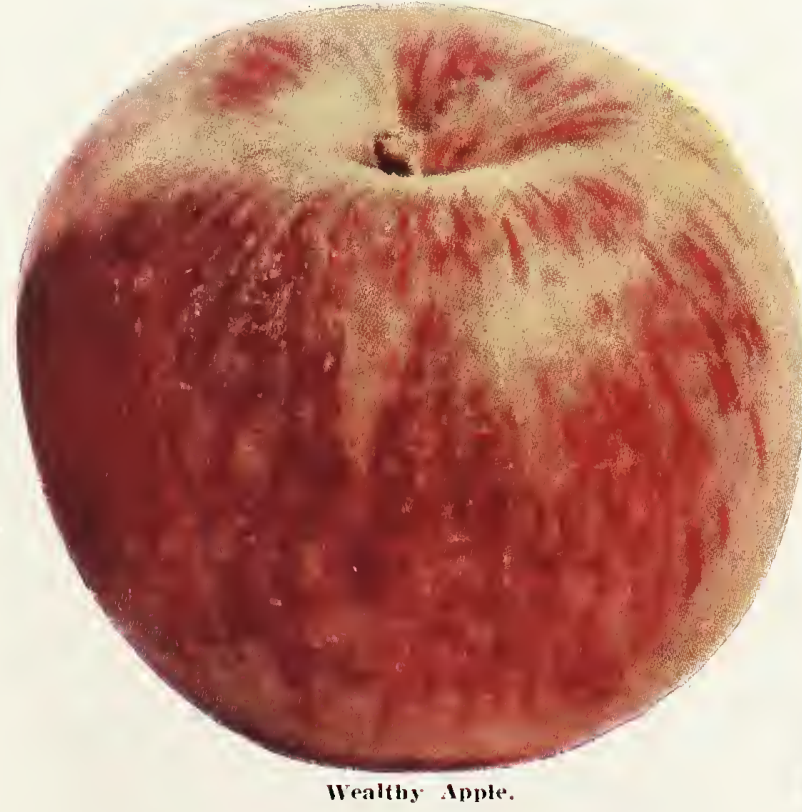

\section{A Well Pleased} Customer

Easton, $\mathrm{Pa}, \quad 9-13-20$ It is with a sense of pleasure that I am writfortune I have had with the trees ordered from you in the spring, 1919. One of the Dwart Duchess of Oldenburg apple trees. plantedty-on August 19,1920 , and bore eight well formed apples this season. I have one otrer of this same variety. borty-one inchestal wh bam set of stork ordered last year there are stil. others that have borne or are still bearing apples this season. This sperks thell for Hall nursery stock and now that it his stock is an opportunity to know that the stork is true to name. COLLINS TRITTENBACH

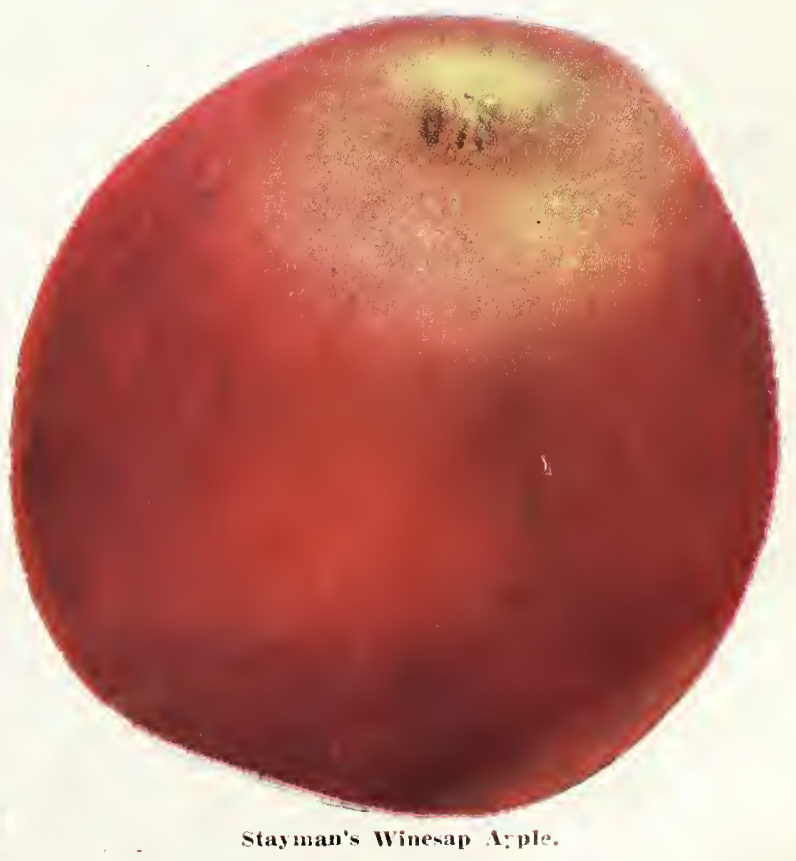



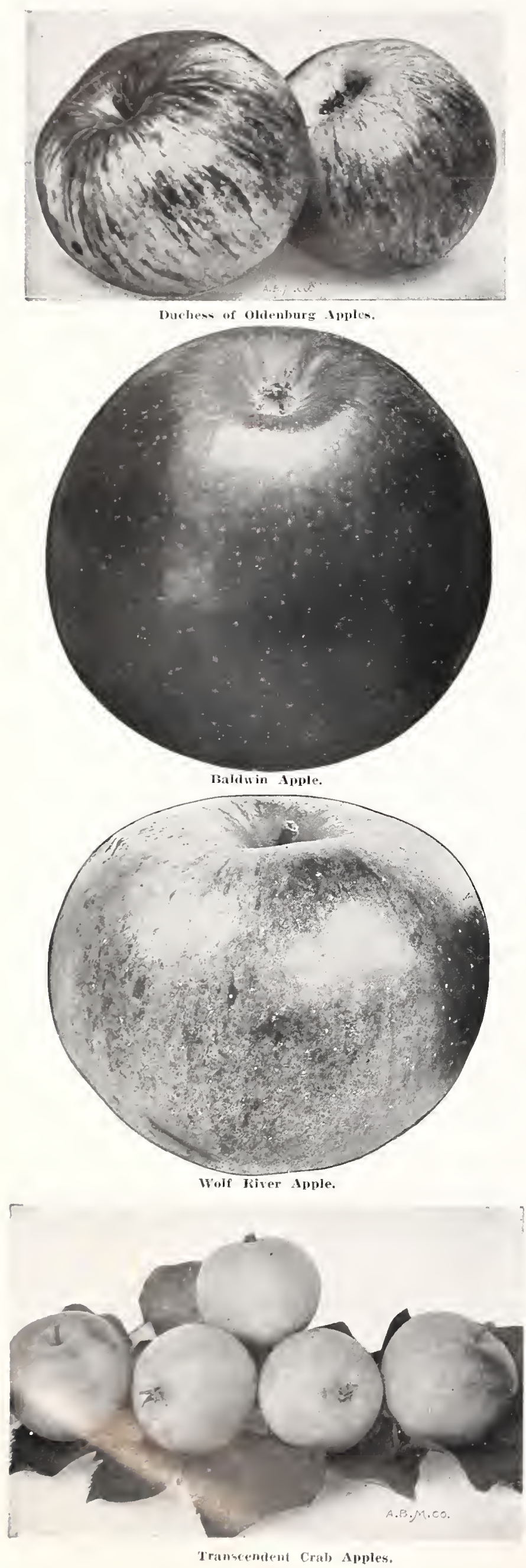

\section{Winter Apples}

BALDWIN. Large, deep red: crisp and juicy, of finc, rich, sub-acid flavor and delightful aroma. Keeps splendidly well into winter: an excellent shipper. The market always pays well for Baldwins. A quick, strong grower.

DELICIOUS. The National Dessert Apple. Successful wherever Apples grow. Large, conical shaped, beatufully colored, striped red over yellow. Flesh tender, with rich. distinctive Aavor, very aromatic and pleasant to the taste. Truly Delieicus. Ilady, bears young and abundantly. Brings more money per box than other sorts bring per barrel.

GOLDEN RUSSET. Medium size. clear golden russet with slight blush. Juicy and ligh tharored.

GRIMES' GOLDEN. The most poptular golden apple, prized for its beanty and quality. Golden, transparent yellow, tender, rich and delicions; keeps well without Insing any of its crispness or flavor. One of the best for faney box trade.

HUBBARDSTON (Nonesuch or American Blush.) Large, striped yellow and red; tender and juicy

JONATHAN. Brilliant red aple of high flavor. Juicy, fine-grained, tender. 1.roductive; bears young.

KING OF TOMPKINS COUNTY. Superb red apple of extraordinary size and fair quality.

McINTOSH RED. Fruit bright red, wondrously benutiful, with tender white flesh of s lendid flaver and highesí quality; juicy and aromatic. An excellent shipper. Tree most lardy and vigorous; will bear in three to four years, and has heavy crops. Adated to a wide range of territury.

NORTHERN SPY. Red, twually striped with yellow. Tender, crisp, highest quality. One of the best.

NORTHWESTERN GREENING. Tree vigorous, strong grower, productive. Fruit grecnish-yellow, large, mild. sub-acid. Very hardy.

R. I. GREENING. A great and constant bearer in nearly all soils and situa tions. Large, greenish-yellow; flesh yellow, fine graned, tender, crisp, juicy, sub-acid; fine for cooking. Excellent variety to grow with Baldwin for the commercial orchand.

ROME BEAUTY. Large, handsome, bright red apple. Flavor and quality are above arerage. Comes into learing in three years, and never fails to have heavy crops cach year.

SPITZENBERG (Esorus). Medium, dull red; flesl yellow, firm, juicy, delicious, sub-acid.

STAYMAN'S WINESAP. Truly a great apple. Dark, rich red. striped with yellowish green. Firm, fine grained, exceedingly juicy and spicy. Wonderfully roductive.

TALMAN SWEET. The best winter sweet apple. Medium, pale whitish-ycllow: Hesh white, fine graincd; much esteemed for baking and cooking.

WEALTHY. One of the best money-making sorts. Bears young. Heavy crops annually. Brilliant red, large and handsome. Splendid quality. Good keeper. Extremely hardy. One of the most profitable varicties.

WINTER BANANA. An excellent new apple. Very showy in appearance large size. roundish, deep yellow with red cheek, heavily waxed; attracts at tention at once. Tender and delicions, with banana perfume.

WOLF RIVER. Highly colored red giant show apple. Flesh white, sub-acid, good quality. Tree very hardy and productive, bears early and annually; most frofitable commercial variety; 80 to 100 apples fill a bushel box.

\section{Crab Apples}

HYSLOP. Large, dark red, sub-acid.

TRANSCENDENT. Large, yellow with crimson cheek.

WHITNEY. Large, greenish, striped with carmine. Juicy and rieh.

\section{Dwarf Apples}

Set trees 8 to 10 fect apart. Very roductive, usually commence bearing the econd year after planting. Excellently adapted to yard and small gardens.

\section{Priee of Dwarf Apples, \$1.25 Eaeh.}

We can furnish the following varicties in Dwarf Apples; for descriptions of fruit see same varieties moler Standards.

Yellow Transparent Duehess of Oldenburg

McIntosh Red

Red Astrachan
Wealthy

Baldwin

Rhode Island Greening

Delicious 


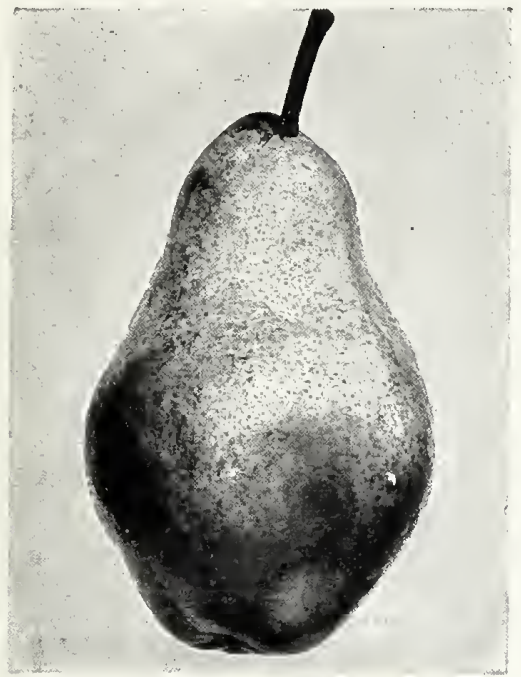

Biartlett.

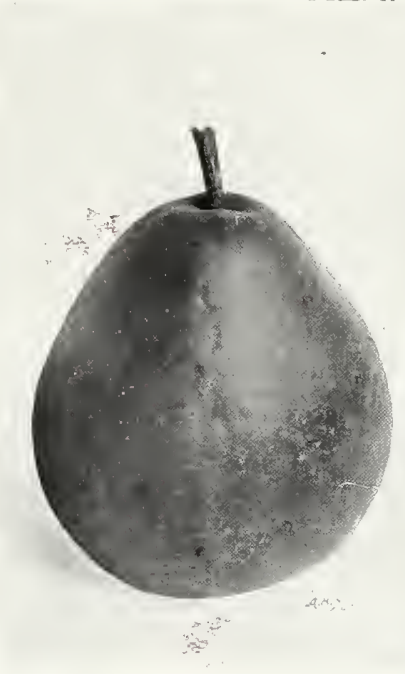

sereliel

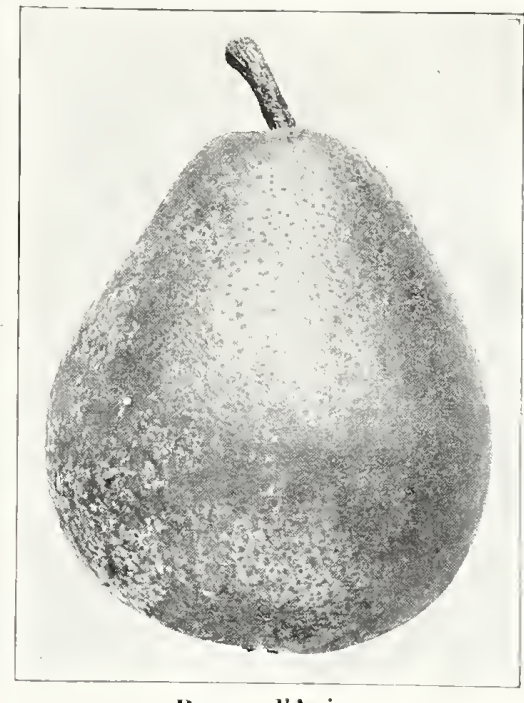

Beurre d'An,jou.

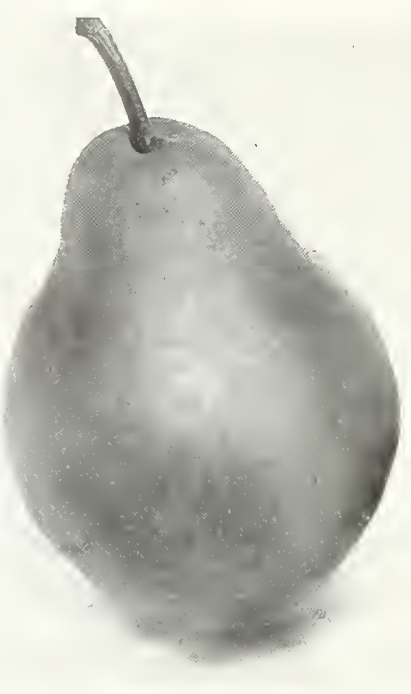

Clapp's Faverite

\section{Standard Pears}

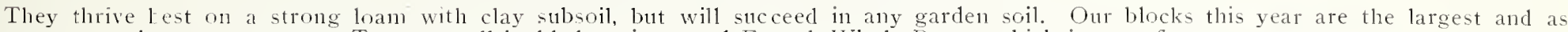
fine as any we have ever grown. Trees are all budded on imported Fronch Whole Ronts, which insures finest root system.

Price of Standard Pears (except Beurre Bosc), extra fine, selected trees, 2 and 3 year:

5 to 7 feet

4 to 5 feet

\section{Summer Pears}

BARTLETT. General favorite. Large, beautiful and excellent; yellow, tinged with red; buttery and melting; rich, musky flavor.

CLAPP'S FAVORITE, J arge, showy, fine looking pear of good quality. profitable for market. Golden yellow with red cheek; melting, juicy, with sweet, delicate flavor.

\section{Autumn and Winter Pears}

BEURRE D'ANJOU. Equals Bartlett in quality. Large, handsome, greenish-yellow blushed with crimson. Tree hardy, succeeds everywhere, bears heavy crors.

BEURRE BOSC (Thanksgiving Pear). Extra large, superl) quality Deep russet yellow. Flesh white, rich and delicions. Keeps well until Chris'mas. Pice. $\$ 1.50$ e ch.

DUCHESS D'ANGOULEME. Large, greenish yellow; tender, but tery. Best as dwarf.

KIEFFER. Wonderfully abunclant regular bearer. Always sells at good prices. Golden yellow when ripe: flesh white crisp juicy.

SHELDON. Medium size. round, russet and red. melting, rich, very juicy, delicious. Fine for dessert; very roductive; keeps well October.

\section{Plums}

Each 100

$1.00 \quad 9.00 \quad 80.00$

SECKEL (Sugar Pear). Small, finest flavor; excellent for pickling and dessert.

NORDEN-SECKEL. An improved Seckel; golden yellow with bright crimson cheek; flesh white, buttery, fine grained, and melting; tree an upright, vigorous grower, very hardy, abundant bearer.

\section{Dwarf Pears}

2- and 3-year, extra fine, 3 to 4 feet: Each, 85 ; per $10, \$ 7.50$; per 100 , $\$ 65.00$

The dwarf varieties require less than one-fifth the space necessary or the standard varieties, and though the tree is dwarf the fruit is ame size as standard, and is lorne in laroe guantities. It is valuable oth for the home garden and orchard planting for commercial puroses. It is a good filler for apple or standard rear orchards, because 't is an early bearer and takes up but a small snace. Trees slould be 'Tanted ten feet apart. We can furnich the following varieties in Dwarf (for descriotion see Standard Pears.)
Bartlett
Clapp's Favorite
Beurre D'Anjou

\section{Seckel}

Extra fine, selected trees, 2 - and 3 yr., 5 to 7 feet.

Each $\quad 10 \quad 100$

$\$ 1.25 \$ 11.50 \$ 100.00$

BEAUTY OF NAPLES. cellent flavor.

BRADSHAW. Large, hand some, bluish-purple; juicy, excellent. Very productive.

FELLEMBERG (Italian Prune.) Largest size, superb quality; rich,

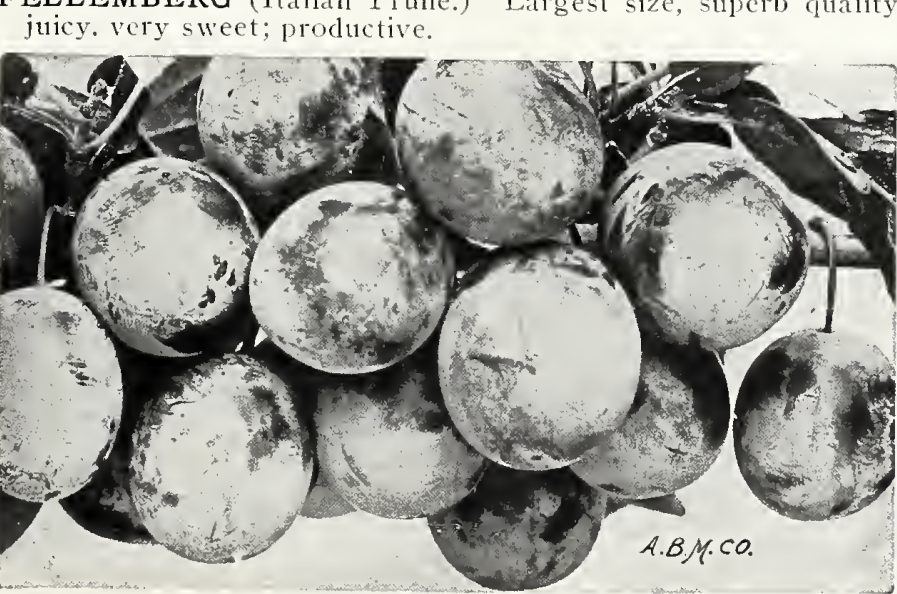

Burbiuk plums.
GRAND DUKE. One of the best late plums. Dark, violet red; juicy, GERMAN PRUNE. Grows to perfection everywhere; very hardy, very productive. Large, dark blue with dense bloom; juicy, sweet, rich and pleasant.

LOMBARD. Most popular and widely planted variety in America. Large, violet-red, juicy and good.

MONARCH. Large, dark purple, delicious quality, juicy, very free from stone. Tree strong grower, bears young, yields abundant crops. One of the most valuable and profitable varieties.

REINE CLAUDE (Green Gage). Large, juicy, melting, sugary, delicious. Hardy and very productive.

SHIPPER'S PRIDE. Very large, dark purple, juicy, sweet. fine quality. Excellent for all purposes.

SHROPSHIRE DAMSON (Prune Damson). Nost popular Damson in America. Does well everywhere.

YELLOW EGG. Large, golden-yellow, sweet and mild.

\section{Japanese Varieties}

ABUNDANCE. Large; amber, turning to bright red. Juicy, tender, delicious; freestone. Hardy, productive.

BURBANK. Very large, rich dark red; tender, very juicy, rich, sweet, and aromatic. Hardy, productive.

RED JUNE. Fruit medium to large, deep vermilion red, very showy, flesi light lemon yellow, slightly sub-acid; half cling, pit small. Tree hardy, upright and productive. Very early. 


\section{Cherries}

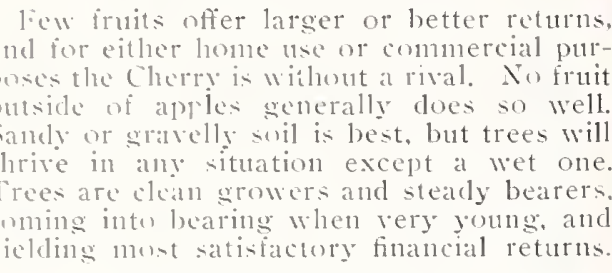

\section{Sour Cherries}

Extra fine, selected trees, 2 yr., 5 to $6 \mathrm{ft}$. Each, \$1.00; ten, \$9.00; hundred, $\$ 80.00$. EARLY RICHMOND. Medimm size, dark red, melting and iticy. acid flaror. Very hardy excecdingly productive.

ENGLISH MORELLO. The standard late sonr cherry. Large and handsome, dark red, becoming almost black. Fruit arood quality, tender, juicy, acid, rich. MONTMORENCY. Beautiful, large, red. cher of great value, very profit ble: more largely planted for market than any other. Hardy, vigorous, very roductive; the greatest money-maker i1 the list.

\section{Sweet Cherries}

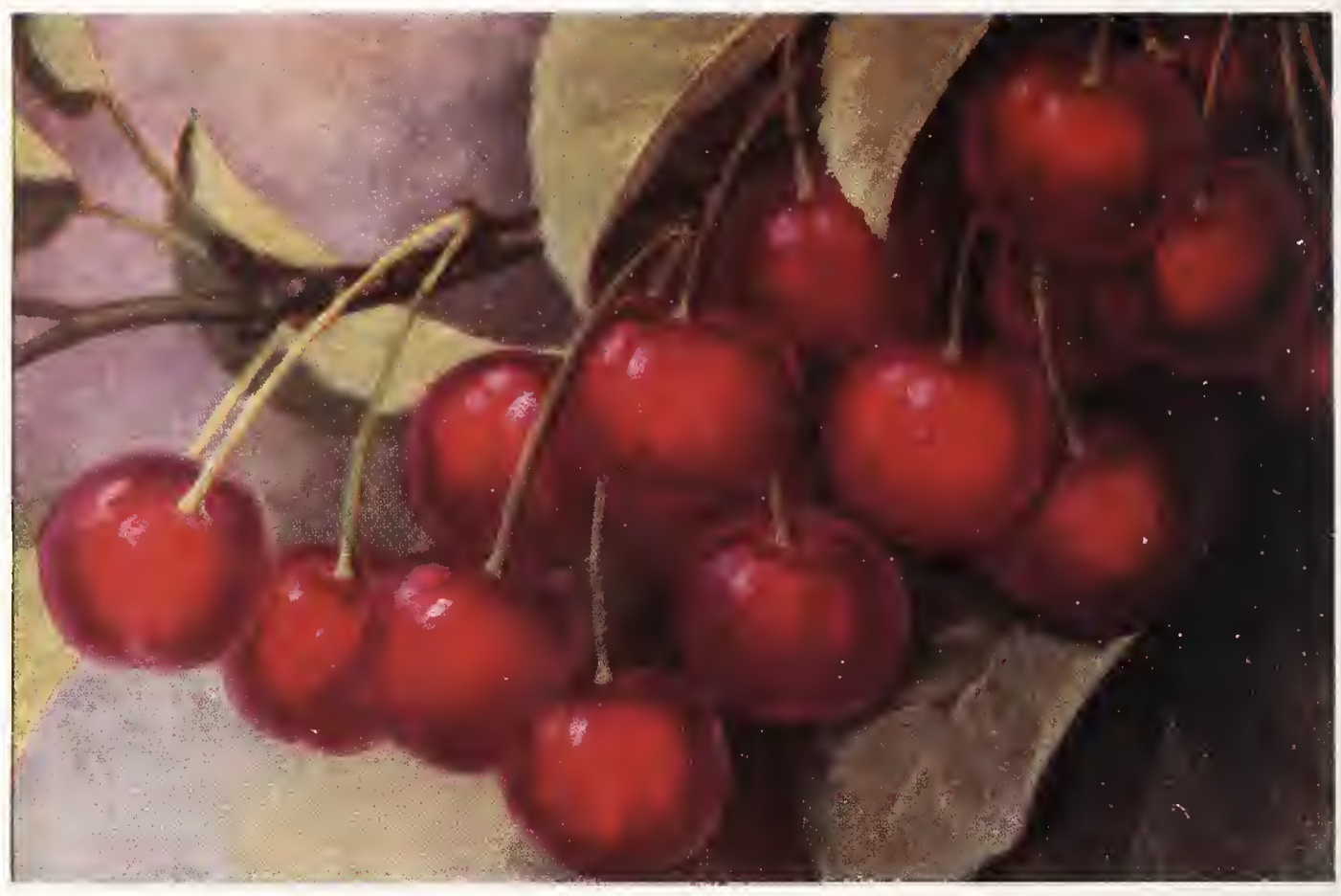
Extra fine, selected trees, 2-and 3-year, 5 to $7 \mathrm{ft} . \ldots \begin{array}{ccc}\text { Each } & 10 & 100 \\ \$ 1.25 & \$ 11.50 & \$ 100.00\end{array}$ BING. A new black cherry; size large; color blackish-purple; flesh chand of the highest havor.

BLACK TARTARIAN. This fine old variety produces immense cro:s of very large. purple-black fruits of high quality; juicy, meaty, mild and sweet.

GOVERNOR WOOD. Very large, rich; light yellow with red cheek; inic and sweet. One of the very best.

NAPOLEON. Very large, yellow and amber with bright red blus! Aesh firm: inicy and delicions. Bears enormous croms.

SCHMIDT'S BIGARREAU. Unsurpassed in size. Glossy black. flesh crisp, firm, juicy, sweet, rich flavol.

WINDSOR. Large liver-colored cherry, remarkably firm and gond. YELLOW SPANISH. Large, rale yellow with light red cheek: firm

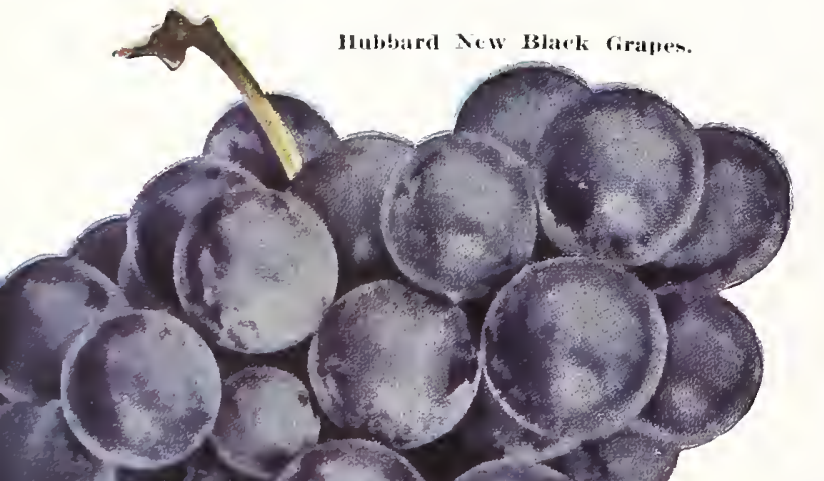

\section{Extra strong, 2 ard 3 -year, 4 to 5 feet:} hundred, $\$ 100.00$

ORANGE (Apple). Best of the older sorts. Very large, bright golden vellnw, fine qualit

REA'S MAMMOTH. Larger than Orange, tree more vigorous and productive. Ripens very carly.

\section{Apricots}

SUPERB. The kest Apricot now offered. Perfectly hardy. has no superior in productiveness. Beautiful vellow with slight blush: flesh firm and solid. One of its many desirable traits is its long season, covering a period of three weeks. Price, $\$ 1.00$ each.

\section{Grapes}

Extra strong select 2 -yr. vines with long tops and good roots. Price, except noted, 50 cents each; $\$ 4.00$ per $10 ; \$ 35.00$ per 100 . If by parcel post, add 2 cents per plant.

BRIGHTON (Red). Large bunch and kerry. Highest quality. Hardy.

CACO (Catawba Concord). A perfectly hardy grape that equals the finest hot-house r roduct in its delicious quality and melting texture. Beautiful large berries, wine-red, with a! lundant llomm, rich in segar. Bunch gond size, compact and of good form. Ripens before Concord. Vines very strong growers, healthy, and prolific bearers. Price, 75 cen's each.

CAMPBELL'S EARLY. New Early Black Grape; most valuable for market. Flavor rich, sweet. Eunch and berry extra large.

CATAWBA. One of the best late keepers, lasts till February nr March. Fine quality, largely used for wine and champagne. Large, covery-red berres, purplish when fully ri. e.

CONCORD (Plack). The great Business Grape; succeeds everywhere. 35 cents each; $\$ 3.00$ per ten; $\$ 25.00$ per hundred.

DELAWARE. A delicious little red table grape; juicy, sweet, hardy, productive.

DIAMOND. Dclicious early white gra:e; large, juicy, rich. Hardy; productive.

HUBBARD. A superb new grape for table use. Ripens ten days earlier than Concord. A rich blue in color, bears heavy. Runch and berry large and uniform, skin thin and very firm, pulp tender, with sweet and delicious flavor. Price, 75 cents each.

LUCILE. New red grape. Extra hardy: crops exceed Concnrd. Gond quality, clusters and berries large, attractive in form and color. The beauty of the fruit will always sell it at extra high prices.

MOORE'S EARLY. Ten days earlier than Concord. Large, purplish-black berries, sweet and very good. Extremely hardy.

NIAGARA. The leading white grape for market. linch and berry large, fine flavor. Harly, and a great yielder.

WORDEN (Black). Bunch large and compact, lerry round, black with blue bloom; pulpy, juicy and very pleasant; ripens scveral days earlier than Concord. 


\section{Currants}

Note-On account of Federal quarantine, no orders for Currants can be accepted for shipment West of Mississippi River.

Price of Currants (except noted), Extra strong 2-year No. 1: Each, 25 cents; ten, $\$ 2.25$; hundred, $\$ 20.00$.

CHERRY. The standard red Currant. Fruit very large; valuable alike for market and garden; splendid quality.

FAY'S PROLIFIC. One of the very best and most popular red Currants. Very productive, hardy and vigorous; of the finest quality.

PERFECTION (New). One every small fruit grower should have. Originated at Rochester, N. Y.. awarded the Barry Gold Medal and other first prizes. Hardy, very productive. Color an attractive red; flavor and quality the best; juicy, tender, sprightly, sub-acid. Clusters long and compact; berries are uniformly large to the tip of cluster. $35 \mathrm{c}$ each; $\$ 3.00$ per $10 ; \$ 25.00$ per 100 .

RED CROSS. A strong growing variety. Cluster long; berry medium to large, bright red; quality good to best. Exceedingly productive, and currants are of large size. Sweeter than ordinary currants.

WHITE GRAPE. Greatest of the white varieties. Delicious, mild, excellent quality; good for table use; very distinct and valuable. Immensely productive.

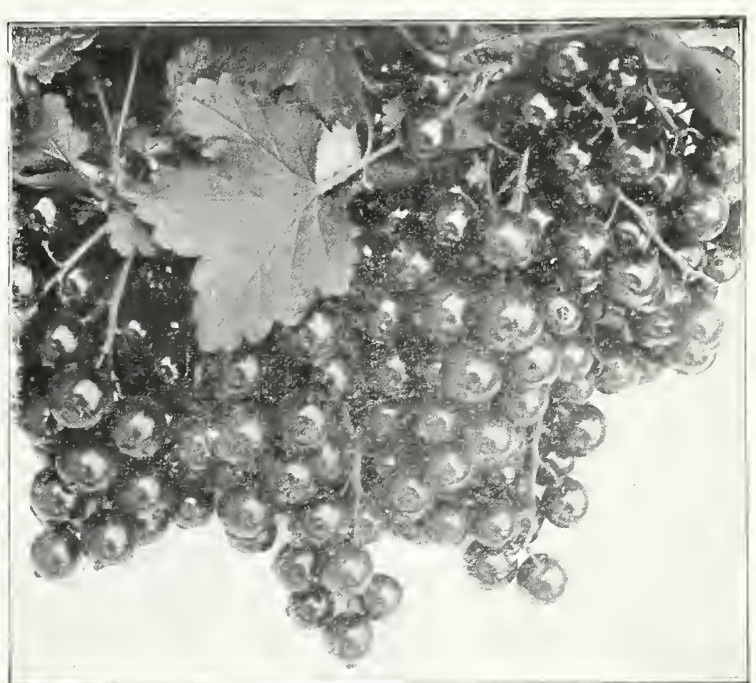

Perfcction cusauts.
Everyone who has a place to grow any trce should grow a nut tree.

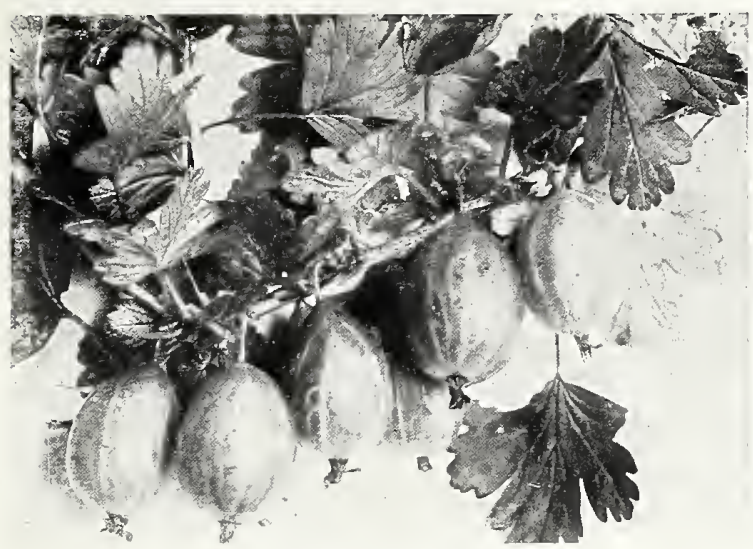

Downing Gess:berits.

\section{Gooseberries}

NOTE.-On account of Federal Quarantine, no orders for Gooseberries can be accepted for shipment West of Mississippi River.

Strong 2-and 3-year plants.

CHAUTAUQUA. Light yellow, largest size, 1 to $1 \frac{1}{2}$ inches in diameter; very sweet and delicious. 50c each; $\$ 4.00$ per 10.

DOWNING. The Business Gooseberry. Pale green; juicy, sprightly and sweet. Strong grower, very productive. 35c each; $\$ 3.00$ per 10.

RED JACKET (Josselyn). The best of the American sorts, as large as the largest knglish variety. Strong, vigorous grower, hardy, wonderful cropper. Berry rich, juicy, highest quality. 50c each; $\$ 4.00$ per 10.

Note.-If by parcel post add 2 cents per plant.

About four Lyme Pa., J×n. 19. 1922. About four years ago I bought of you several peach trees of the New Hale variety, and the pust year my trees were full of peaches and almust every one of them weighed about thre IGNATZ WAGNER

\section{Blackberries}

Price, strong root cuttings, not sucker plants, $\$ 1.50$ per doz., $\$ 7.50$ per 100 . If by parcel post, add 1 cent per plant.

BLOWERS. The Best Blackberry. Originated in the celebrated small fruit belt of Chautauqua County, N. Y., where it has been thoroughly tested several seasons. Claimed to be the hardiest, most productive, the finest quality, and to bring on the market the highest price of all blackberries. Has produced 2694 berries on one bush, 2720 quarts on one-third acre. Large size, jet black, good shipper, best quality, unexcelled productiveness are the main characteristics of this splendid new sort.

ELDORADO. A strong growing hardy variety; very productive; fruit very large, jet black, in large clusters, ripening well together. Its keeping quality is unsurpassed. Fine quality, sweet, without core.

RATHBUN. Fruit borne in clusters, berries very large, color intense black with a high pol ish; small seeds; flesh juicy, high flavored, sweet and delicious. In season medium early.

\section{Asparagus}

Strong 2-year plants, $\$ 1.00$ for 25 ; $\$ 2.50$ per 100.

GIANT ARGENTEUIL. Very early, produces heavy crops of the largest white stalks. Makes good show in market, always brings the best prices.

CONOVER'S COLOSSAL. Standard kind of first quality.

PALMETTO. Fine early variety of large size.

Note.-If by parcel post add 25 cents per 100 plants.

\section{Rhubarb}

Strong 2-year whole roots.

;TRAWBERRY RHUBARB. Early, tender, without being in the least tough or stringy; color a beautiful strawberry red. $25 \mathrm{c}$ each; 10 for $\$ 2.00$.

JHAMPAGNE RHUBARB (New). Excels all in size, flavor, and delicate tenderness of its crimson stalks. Brings highest market price. $35 \mathrm{c}$ each; 10 for $\$ 2.50$.

Jote-If by parcel post add 2 cents per plant.

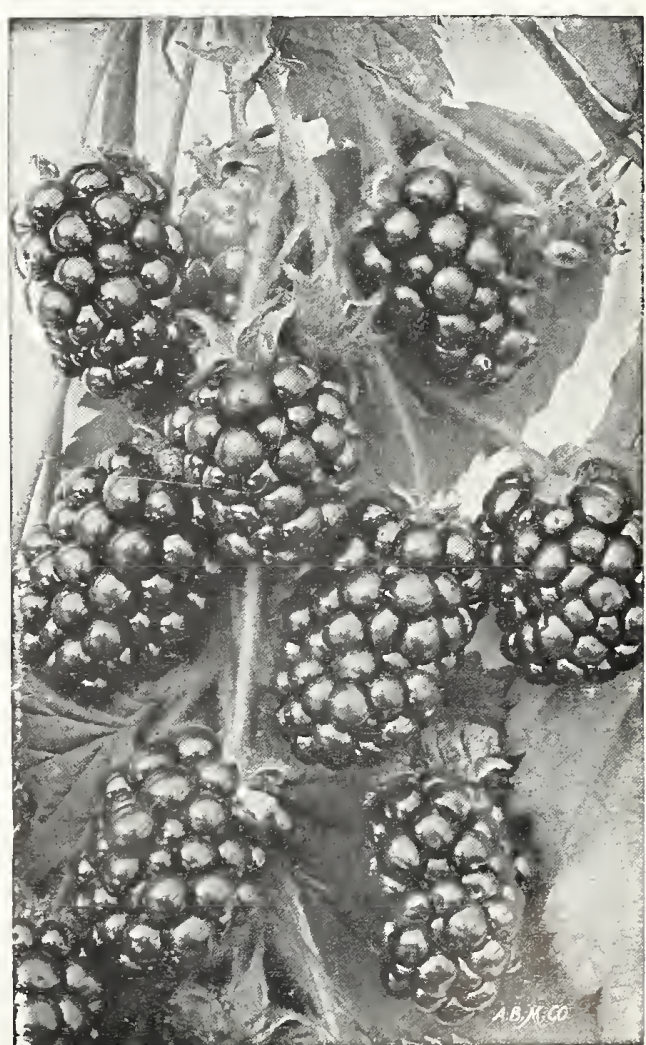

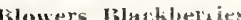




\section{Raspberries}

\section{Black Raspberries}

Price, $\$ 1.00$ per dozen; $\$ 4.00$ per 100 .

Note. - If wanted sent parcel post add 1 cent per plant.

CUMBERLAND. Largest of the Black Caps. The most profitable variety for main crop. A healthy, woors grower, throning up stont, stoeky. Well

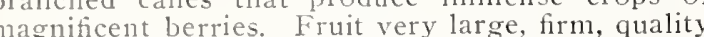
as keeps and ships as well The most profitable market

PLUM FARMER. Wonderful new berry, one of the best for all sections. This very large and productwe thoroughly tested in Where it is a great favorite for market or home use. It is covered with a grayish bloom like the bloom on a grape. It ripens very early and quickly The fruit is enormously large.

\section{The New Blackcap Raspberry Honey Sweet}

distinct new variety, originated in Western New York, regarded besperry yet introduced. Fruit very ext sweet and refreshing. Hardy, bears every year in great abundance. Price, $\$ 2.00$ per doz., $\$ 10.00$ per 100.

Willers Falls, Mass, May 2, 1921.

Your catalogue was handed to me by a man who has purchased elaims he always got satisfaction 列 GEO. W. MERRIOTT

Orleans, Mass., May 9, 1922 Trees just received from you are so fine I am sending you another G. E. T, WARD.

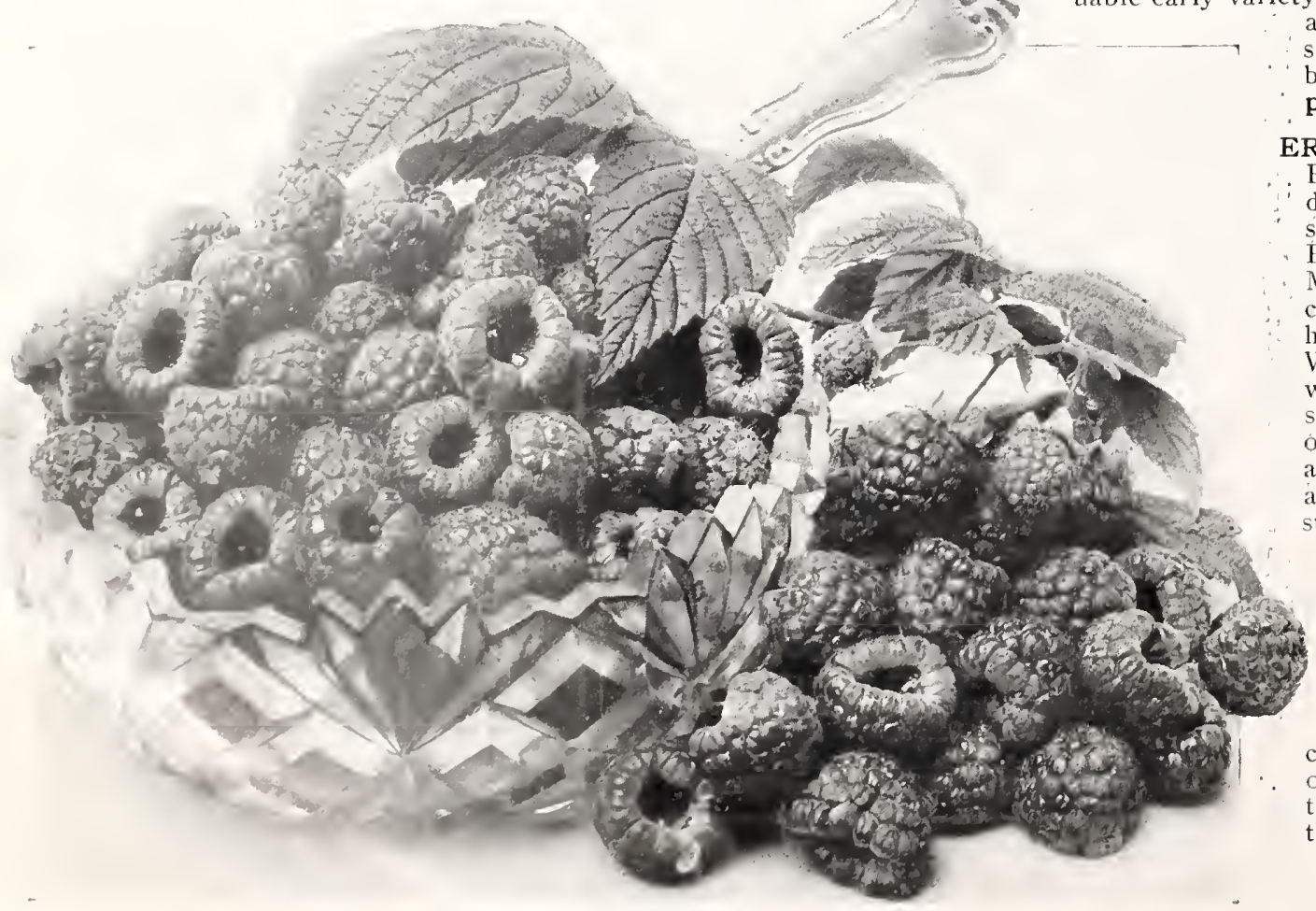

\section{Red and Purple Raspberries}

Price of Raspberries (except where noted), $\$ 1.00$ per doz; \$4 per 100

Note.-If by parcel post add 1 cent per plant.

COLUMBIAN. Fruit very large; color dark reddish purple; adheres firmly to the stem; seeds small; has a distinct flavor of its own, making it a most delicious table berry. For canning purposes it is much superior to any other. Bears enormous crops,

CUTHBERT or QUEEN OF THE MARKET. Large, rich crimson; sweet, rich, luscious. Leading market variety for main crop. Hardy.

HERBERT. The Raspberry with the real Raspberry flavor. Takes first place in hardiness. Bright red; very sweet and juicy. Enormously productive. Price, $\$ 1.25$ per doz.; $\$ 5.00$ per 100 .

GOLDEN QUEEN. Large, beautiful translucent yellow color and exceptionally firm; very productive. The canes are of the strongest growth and quite hardy. Price, $\$ 1.25$ per doz.; $\$ 5.00$ per 100 .

EARLY JUNE. Earliest of all Red Raspberries, and the most valRipens in June. Fruit large, quality the best and one of the most productive. Keeps and ships well and on account of its early bearing. brings the highest prices. Price, extra strong plants, $\$ 1.25$ per doz.; $100, \$ 5.00$.

ERSKINE PARK. A New Everbearing Red Raspberry for which there will be an immense deniand as soon as its merits are known. A seedling of the Cuthbert. originated at Erskine Park, the Estate of Geo. Westinghouse, at Lee, Mass. Berries very large for a Red Raspberry, conical, juicy and of fine flavor. Very hardy, having stood the winters in Eastern New York. Western Massachusetts and Southern Vermont without injury. Plants very strong growers, surpassing St. Regis or Ranere in size and quality of fruit and in productiveness. This variety is a very heavy feeder, likes plenty of manure, and a few good waterings during the dry part of the ummer helps out. Does best when canes are cut close to the ground every spring. Price, $\$ 2.00$ per doz.; $\$ 10.00$ per 100 .

ST. REGIS (Ranere) EVERBEARING RED RASPBERRY, Greatest money maker ever produced. Bears fruit four months first season planted. Begins to ripen middle of June. Wonderfully prolific, main crop as great as any other red variety, summer or autumn crops full to heavy pickings all the time. Berries large, firm and full flavored until the very last; rich, sugary. Hardy. 


\section{Strawberries}

Extra fine plants from fresh, new propagating beds.

Price of strawberries, postpaid, $\$ 1.00$ per 25 ; $\$ 2.00$ per $100 ; \$ 12.00$ per 1,000 .

PROLIFIC. (New). Originated at $N$

York State Experiment Station; con-

sidered so desirable a commercial

variety that it is being planted ex-

tensively. Perfect blossom.

Plants vigorous and very cro-

ductive; have yielded 14,502

quarts per acre. Fruit ma-

tures in mid-season, ripening

period long; easily picked; berries very large, retaining size well as season advances. Color handsome, bright scarlet: flesh firm, well colored at center, juicy, pleasantly acid.

aromatic; of good quality. On account of the vigor and productiveness of the plants and the attractiveness of the large, uniform, well colored berries, Prolific is well worthy of commercial planting.

BIG JOE. (Joe Johnson) (Joe). One of the most popular shipping berries on nearly all large markets. It is strong grower, making plenty of plants for a good fruiting bed. The berries are large, bright red, and have large, light green caps. which make the berries very attractive, and adds to the selling price. The quality is good and the berries are quite firm. It

is a good shipper, and equally good for fancy local market purposes. Une of the most productive

BRANDYWINE. Berries very large, regular, conical form; color bright glossy red; flesh firm and of excellent quality. Its large size, beatu of form and color, firmmess and high quality will make it a desirable variety for any purpose.

GIBSON (Per.) This variety is comparatively new and is forcing its way to the head of the list very rapidly; it begins to ripen with Senator Dunlap, but owing to its great productiveness it continues to produce till quite late. It is a strong grower, with long roots that withstand dry weather; has dark green, healthy foliage and lots of it. Berry is extra large and vines loaded with fruit. We advise planting Gibson; you will be delighted with them.

SENATOR DUNLAP (Perfect). A variety of great merit, and much admired. Fruit of large size regular anil att-active in form, deep red in color, firm and excellent in quality; season early and

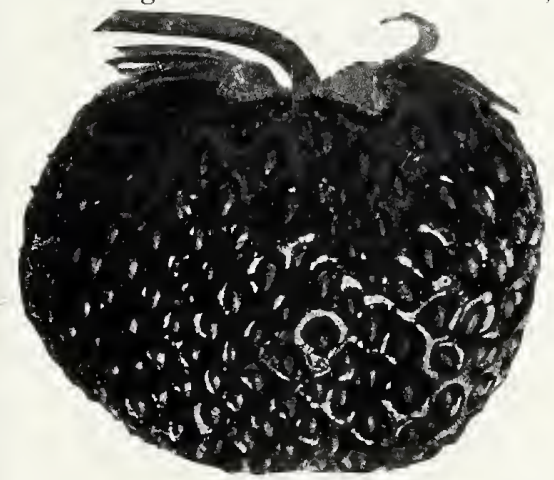
continues in bearing nearly a month.

BUSHEL BASKET. A new strawberry of wonderful nromise; perfect in blossom, plant and fruit. Won the Barry Gold Medal for new fruits of commercial value. Some of the plants have grown so large that a bushel basket will not cover them, hence the name. Originated in the North, full of life and vigne, having the healthiest foliage of any variety grown. Very productive. Berries a beautiful shade of red, extra large, and slightly necked making picking easy; sorightly flavored a good canner, being red to the center, not hollow at the center, nor tough, seeds small. Retains its distinctive straw-
berry flavor after cooking. Price, $\$ 2.50$ per $25 ; \$ 7.50$ per 100 , postpaid.

\section{Everbearing Strawberries}

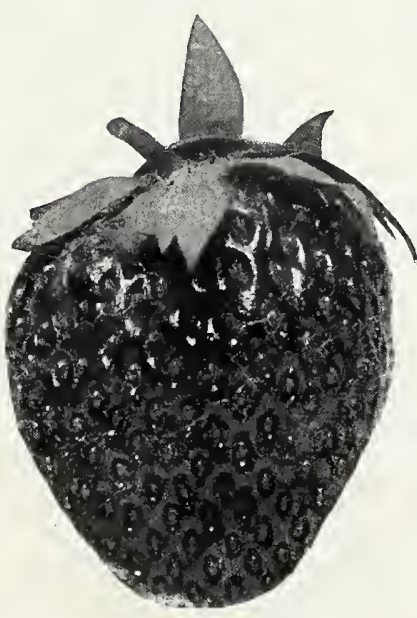

Price, $\$ 1.50$ per $25 ; \$ 2.50$ per 100 (except where noted), postpaid.

PROGRESSIVE. Bears heavily the first summer and fall Berry rather long, dark red, good quality, extra sweet; good shipper. Recommended by Horticultural Societies everywhere. Perfect blossom.

SUPERB. Produces splendid fruit: with us ontyields all other fall bearers. Berries very large, dark red, finest flavor. Perfect blossom.

NEVERFAIL. New Everbearing Strawberry. Originated by D. J. Miller, Millers: urg, Ohio. The most vigorous plant maker, most rroductive and profitable fall-bearing variety. Berries large, holding size well until the last berries flavor. Price $\$ 2.00$ pe: $25 ; \$ 600$ per 100 , postpaid.

Honesdale, Pa., Sept. 20, 1922 I bought of you this Spring trecs, shrubs, bushes, etc., and beg to say they did well, and many looked them over and praised your stock; also prices reasonable. P SONNER

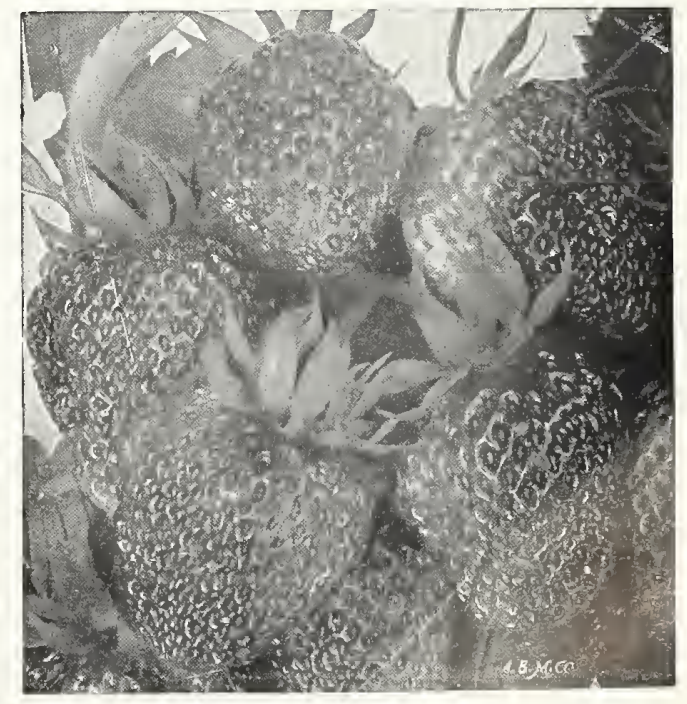

Senator Duniap straviberries.

Progressive Strawberry. 


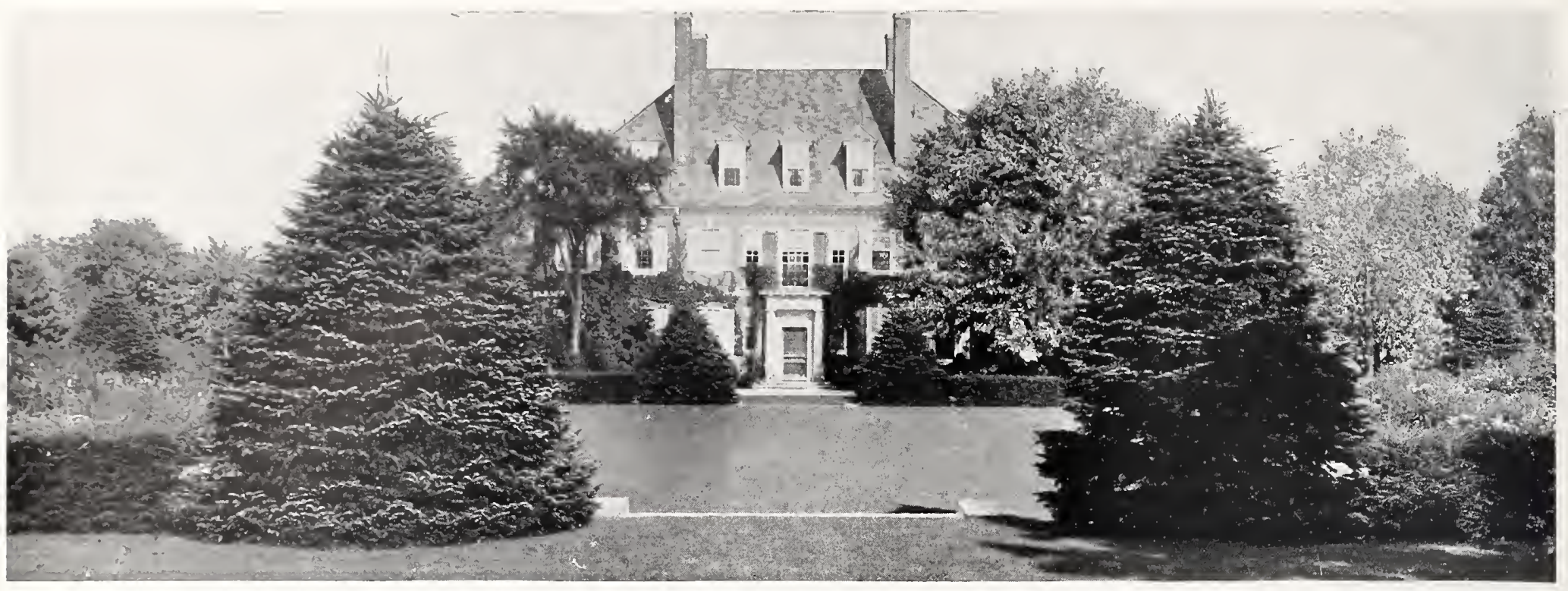

\section{ORNAMENTAL DEPARTMENT}

A fine, well-cut lawn is one of the liandsomest features of a place. Trees and the larger shrubs may be planted along a lane or avenue it. This will secure light. air and a good view from the house. In laystounds, take into consideration economy and labor, and

\section{Trees for Special Purposes}

For City Streets and Avenues-Sugar Mraple, Norway Maple, Ameri- |Weeping Birch, Catalpa Speciosa, Purple-leaf Beech, Mountain Ash, Elm, Pin Oak, American Linden, Oriental Plane, Catalpa Speciosa, the Oaks, Elm, the Lindens.

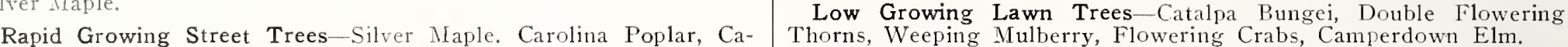
Best Lawn Trees-Norway Maple, Schwedler's Maple, Cut-leaf

Thorns, Weeping Mulberry, Flowering Crabs, Camperdown Elm.

Trees for Screens-Carolina and Lombardy Poplar, Golden Willow,

\section{Deciduous Trees for Shade and Ornament}

BIRCH, CUT LEAF WEEPING. Tall, slender, vigorous growth; 8 feet, $\$ 2.50$.

BEECH, PURPLE (Copper Beech). Highly ornamental and desirable Dark purplish foliage, a
es. 3 to 4 feet, $\$ 3.00$ each.

CATALPA BUNGEI. (Umbrella Catalpa). A unique tree, desiralle for lawn and park. Makes an umbrella-shaped top without CATALPA SPECIOSA. One of the most beautiful lawn or street timber. Very rapid growing. Has magnifi-

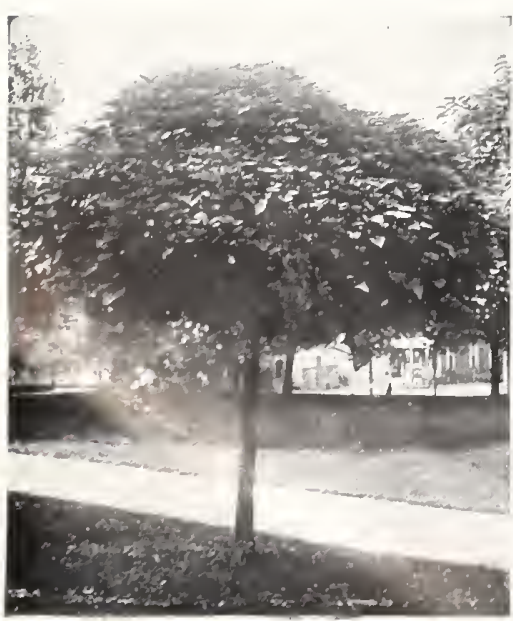

Catalpa remger-Cmbre!! Catulpa.
CRAB, FLORIBUNDA. One of the handsomest and most satisfactory of all flowering trees. Blooms every year without fail. Rose red flowers in great Trofusion in May. 3 to 4 feet, $\$ 1.50$ each.

CRAB, PARKMANII. Bright rose-colored flowers hang on long, slender stems. One of the showiest. 3 to 4 feet, $\$ 1.50$ each.

ELM, AMERICAN WHITE. Noble, spreading, drooping tree. One of the grandest park and street trees. 8 to 10 feet, $\$ 1.50$ each; 10 to 12 feet, $\$ 2.00$ each.

ELM, CAMPERDOWN. One of the best weeping trees. Large, glossy, dark green leaves overlapping to form compact. roof-like head. 6 to $7 \mathrm{feet}, \$ 2.50$ each. HORSE CHESTNUT. Has magnificent spikes of white flowers. 6 to 8 feet, $\$ 2.00$ each.

LINDEN, AMERICAN. (Basswood). Rapid growing; large, fragrant flowers. 7 to 8 feet, $\$ 1.50$ each; 8 to 10 feet. $\$ 200$ each

LINDEN, EUROPEAN. Fine pyramidal tree, large leaves, fragrant flowers. Smaller than American $\$ 1.50$ each; 8 to 10 feet, $\$ 2.00$.

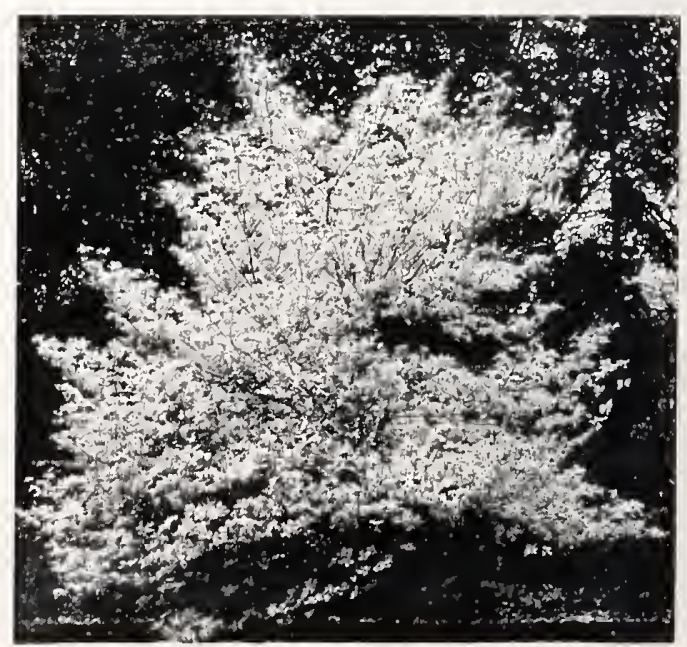

Cornus Morida-White-flowering Doswood. 


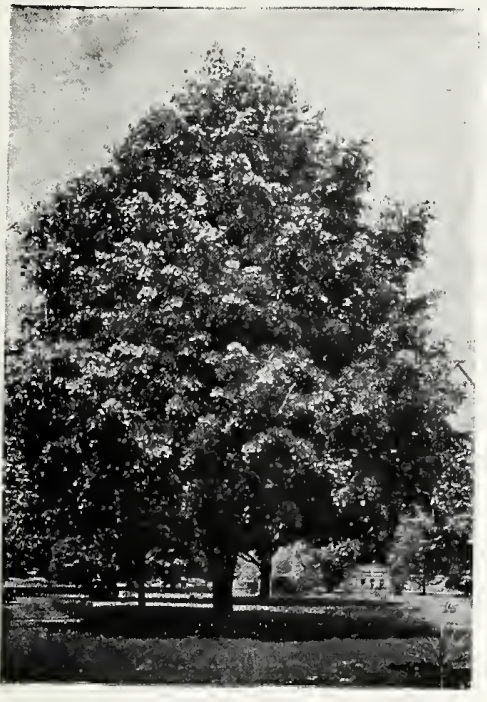

American Linden.
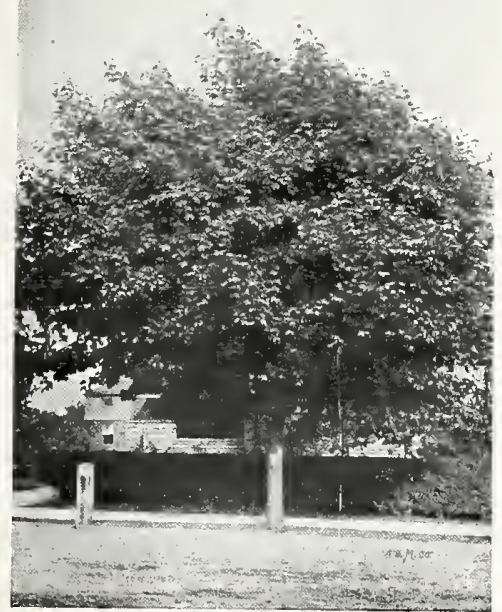

Sugar Maple.

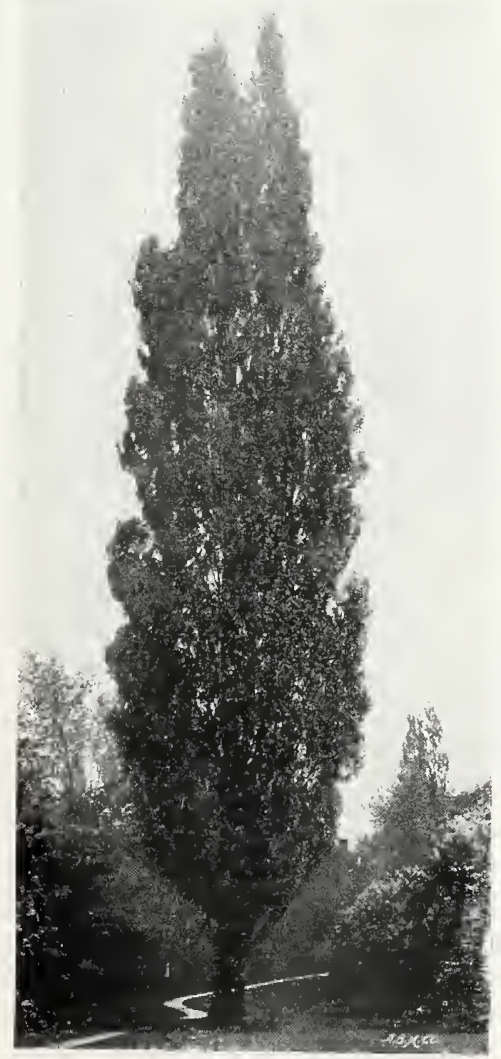

Lombardy Poplar.

MAPLE, Sugar or Rock. Excellent shade tree of large size. Its stately form, rapid growth and fine foliage make it a desirable tree for street, park lawn. 8 to 10 feet, $\$ 2.00$ each; 10 to $12 \mathrm{feet}, \$ 2.50$.

MAPLE, Silverleaf, or Soft Maple. Fast growing. succeeds everywhere; in big demand where immediate shade is required 8 to 10 feet, $\$ 1.25$ each: 10 to 12 feet, $\$ 1.75$.

MAPLE, Norway. (Hard Maple). Most popular shade tree in America. Ideal for street, drive or lawn. Large, handsome tree of fairly rapid growth, with symmetrical round head, broad, shining foliage of deep rich green. 8 to 10 feet, $\$ 2.50$ each; 10 to 12 feet, $\$ 3.00$.

MAPLE, Schwedler's Purple. Very large bronze-re-1 leaves and young shoots of same color. Vigorous growing, handsome ornamental tree. Its beautiful oliage attracts attention at all seasons. 8 to $10 \mathrm{fee}$ $\$ 3.50$.

MOUNTAIN ASH, European. Fine, hardy tree, cov ered from July till winter with clusters of bright red berries. Very ornamental. 8 to $10 \mathrm{feet}, \$ 2.00$ each.

MULBERRY, Downing. Rapid grower. Bears mild. pleasant berries of good quality, 5 to 7 feet, $\$ 1.50$ each. MULBERRY, Tea's Weeping. Perfectly hardy; fine lawn tree; forms natural umbrella-shaced top. 6 to 7 feet, $\$ 2.50$ each.

PIN OAK. A magnificent tree for lawn and street planting, with deep green foliage which changes to a rich scarlet and yellow in the fall; a most shapely and graceful tree. 6 to 8 feet, $\$ 2.50$.

RED OAK. Makes a tree of great height, 50 to 75 feet; a native of large size and rapid growth; leaves dark dull green, turning to orange and brown in autumn; acorns very large; a beautiful specimen tree for park and street planting. 6 to 8 feet, $\$ 2.50$.

PLANE, Oriental. Leaves heart-shaped at base, deeply cut. Is among our tallest trees, growing rapidly into massive proportions. Ilardy and free from disease. 8 to 10 feet, $\$ 1.50$ each.

POPLAR, Carolina. Rapid grower; large, glossy leaves; fine for shade. 8 to 10 feet; $75 \mathrm{c}$ each; 10 to 12 feet, $\$ 1.00$ each.

POPLAR, Lombardy. A ficturesque and ornamental tree, useful in landscape work for screen purposes and to break the average height and form of other trees. Tall, spire-like torm, 10 feet, $75 \mathrm{c}$ each; 10 to 12 feet, $\$ 1.00$ each.

PRUNUS PISSARDII. (Purple-Leaved Plum). One of the finest small trees with colored toliage. Covered with small white single flowers in early spring. 4 to 5 feet, $\$ 1.25$ each.

SALISBURIA. (Maidenhair). A rare, beautiful tree with remarkable fern-like foliage. Rapid growing, highly desirable lawn tree. 6 to $8 \mathrm{feet}, \$ 1.50$ each.

THORN, Paul's Double Scarlet, and Double White. Highly ornamental both in foliage and flowers. 3 to 4 feet, $\$ 1.75$ each.

WILLOW, Babylonian. (Weeping Willow). An old favorite. Tall, graceful, drooping tree with wavy, bright green foliage. 6 to 8 feet, $\$ 1.00$ each.

WILLOW, Golden. Upright growing, very showy va riety with golden bark of high color, very conspicuou in winter. 6 to 8 feet, $\$ 1.00$ each.

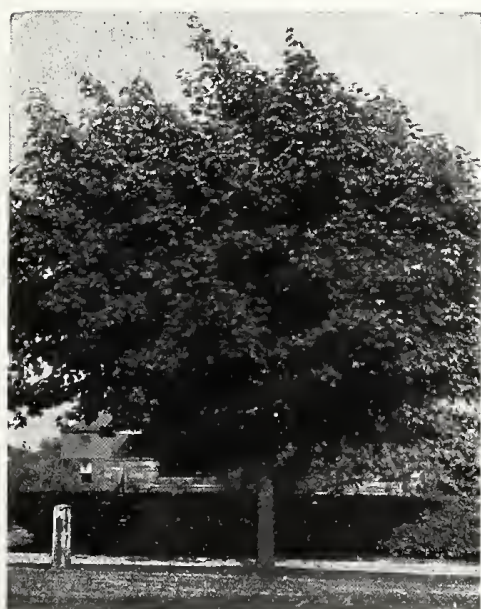

Norway Maple.

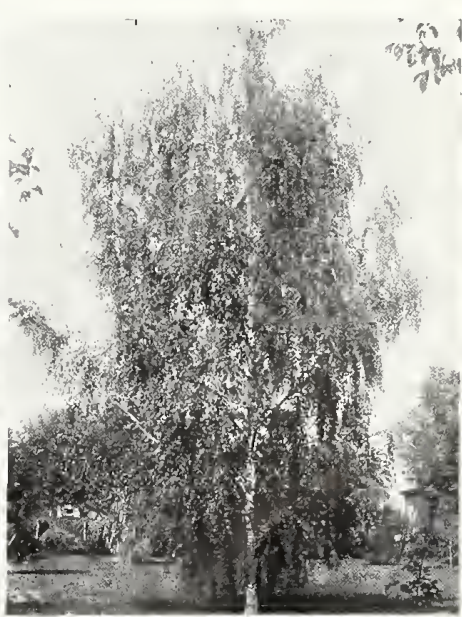

Cut-leaved Weeping Birch.

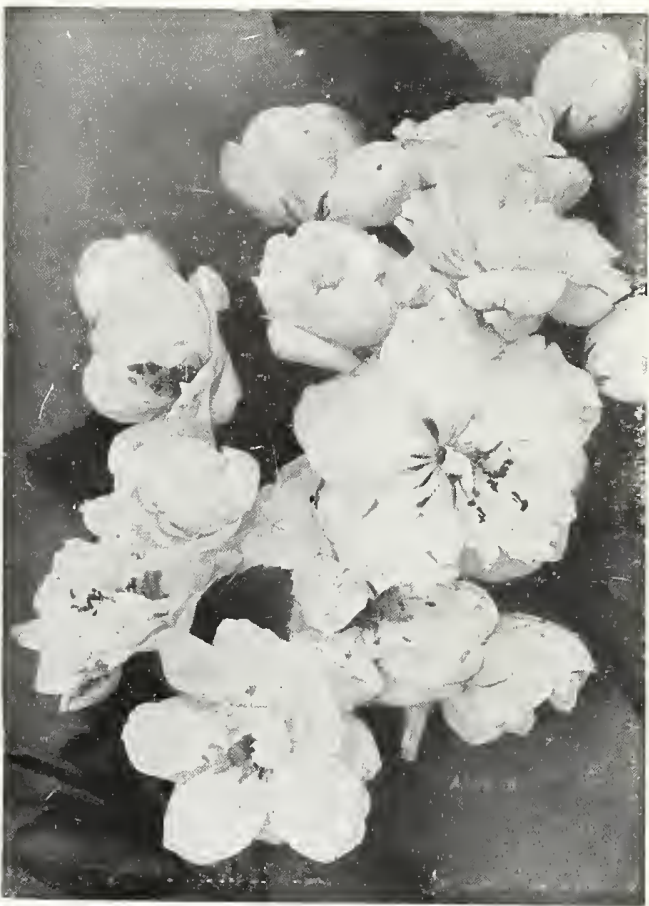

Bechtel's Double Flowering Crah.

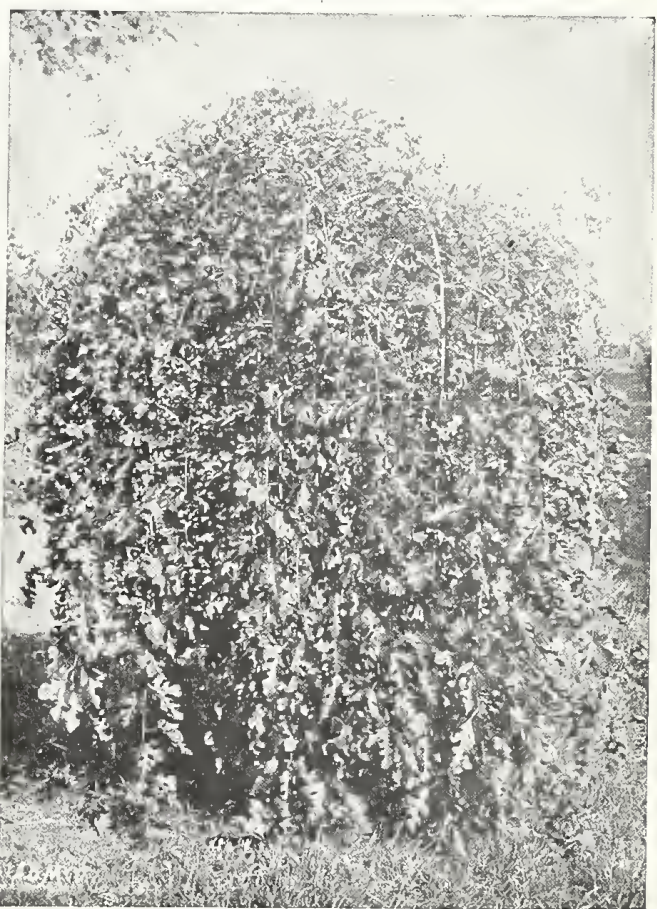

Weeping Mulberry.

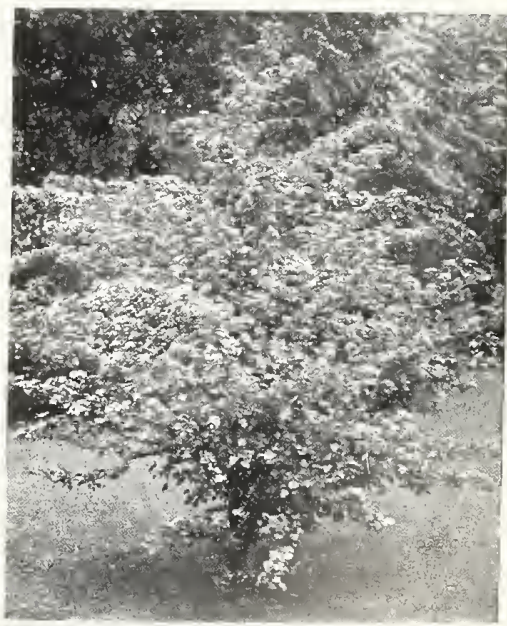

Paul's New Thorn. 


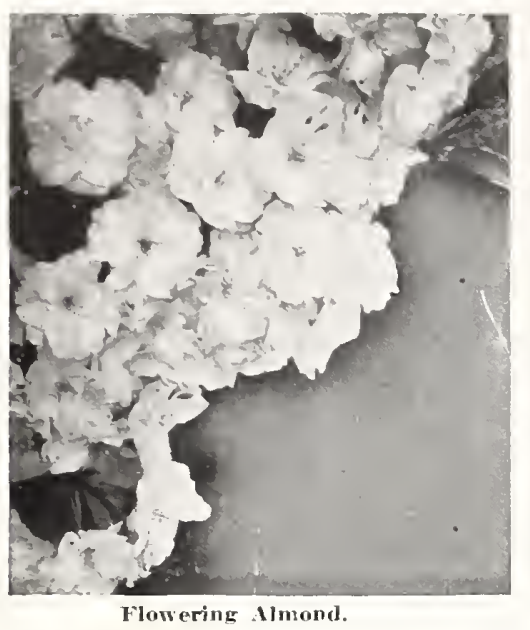

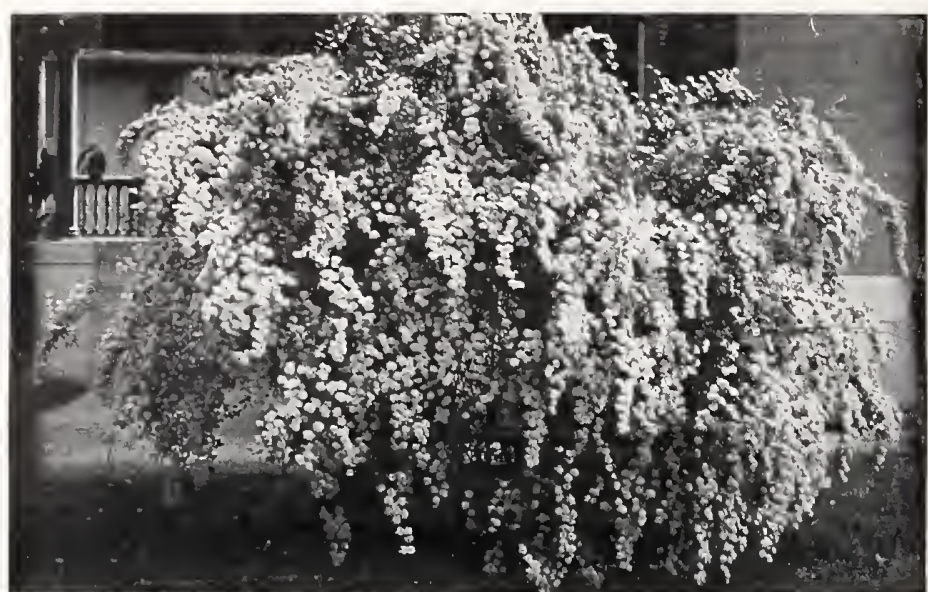

Spirea Van Houttei.

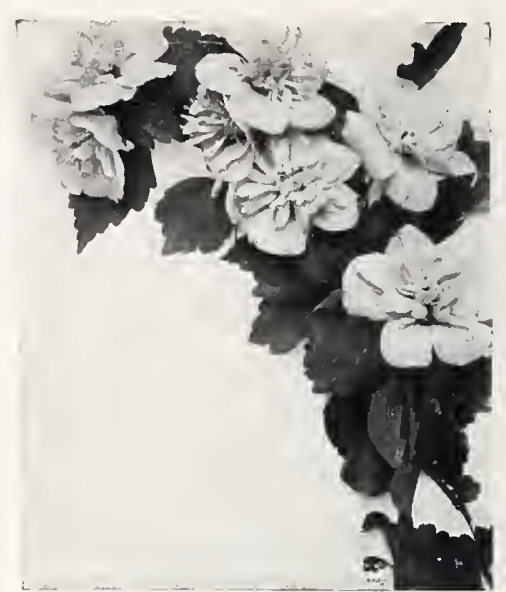

Nitlita, or Rose of Slaron.

\section{Hardy Ornamental Shrubs}

Our Shrubs Are All Strong 2- and 3-year Specimens That Will Give Immediate Effect. Price, (except where noted), 50c each.

Shrubs for Special Purposes

Shrubs with Variegated or Colored Foliage. Althrea Variegated, Barberry, Kerria Variegated, Elder Golden, Prunus Pissardii, Syringa Golden, Weigela, Spirea.

Shrubs that Flower in May. Almond, Forsythia, Honeysuckle. Japan Quince, Lilac, Snowball, Spirea.

In June. Clematis, Deutzia, Dogwood, Honeysuckle, Lilac, Pæonia Herbaceous, Rhododendron, Snowball, Spirea, Syringa. Weigela, Wistaria.

ALMONDS. Pink Double Flowered and White Double Flowered. Covered with small rose-like blossoms in May. Price, $\$ 1.25$ each.

ALTHEA, ROSE OF SHARON. Large, bell-shaped flowers in Au(

Tree Form. The Althea, as a shrub, is fine and attractive, but grown in tree form becomes doubly beautiful and interesting. It is hardy and of easy cultivation. Colors same as preceding. Price, $\$ 1.00$ each. BARBERRY THUNBERGII. (See description under Hedge Plants). Price, 60c each.

CALYCANTHUS-SWEET SHRUB. Flowers in June of a rare chocolate color; deliciously fragrant.

BUDDLEIA (Everblooming Butterfly Bush or Summer Lilac.) Flowers very sweet and fragrant, blooming in spikes of 6 to 10 inches long. CLETHRA ALNIFOliA (Sweet Pepper Bush). Very hardy. Flowers pure white, richly perfumed, Price, 75c each.

DEUTZIA GRACILIS. Dwarf grower, covered with white flowers in June. Price, $75 \mathrm{c}$ each.

DEUTZIA, PRIDE OF ROCHESTER. Very large double white DEUTZIA CRENATA. Double white flowers tinged with rose color. DEUTZIA LEMOINEI. Pure white flowers on stout, upright branches.
In July. Clethra, Clematis, Spirea, Honeysuckle, Elder. Hydrangea Arborescens.

In August and September. Althea, Clematis, Honeysuckle, $\mathrm{Hy}^{-}$ drangea Paniculata Grandiflora.

Shrubs whose Flowers are Succeeded by Ornamental Fruit. Barberry, scarlet berries in September; Elder, purple fruit in August: High Bush Cranberry; Euonymus, red fruit; Rosa Rugosa, Snowberries.

ELDER, GOLDEN. Golden green foliage when planted in sun. White blossoms followed by handsome berries.

EUONYMUS ALATUS. (Winged Burning Bush). One of the most brilliant plants in the landscafe in the fall, with its bright red leaves and berries. Branches winged with a corky layer. Fine specimen shrub or for massed plantings. 3 to 4 feet, $\$ 1.00$ each.

EUONYMUS EUROPAEA. (European Spindle Tree). Bright yellow flowers in spring, followed by clusters of brilliant red berries which hang till mid-winter. Leaves turn to beautiful crimson scarlet in fall. 3 to 4 feet, $75 \mathrm{c}$ each.

FORSYTHIA FORTUNEI (Golden Bell). Upright growing shrub with deep green foliage. Drooping yellow flowers early in the spring before leaves ap-ear. Price, 60c each.

FORSYTHIA SUSPENSA (Weeping Golden Bell.) Similar to above but branches droop like arches of gold. Price, $60 \mathrm{c}$ each.

HYDRANGEA ARBORESCENS STERILIS (Hills of Snow). Grand, new, everblooming. Perfectly hardy. Enormous snow white flowers. Price, 75 c each.

HYDRANGEA PANICULATA GRANDIFLORA. Hardy in all sec(ions. Flowers immense: turning pink with age. Price, $75 \mathrm{c}$ each.

HYDRANGEA P. G., Tree Form. Same as above but in tree form with but a single stem. Very desirable. Price, $\$ 1.25$ each.
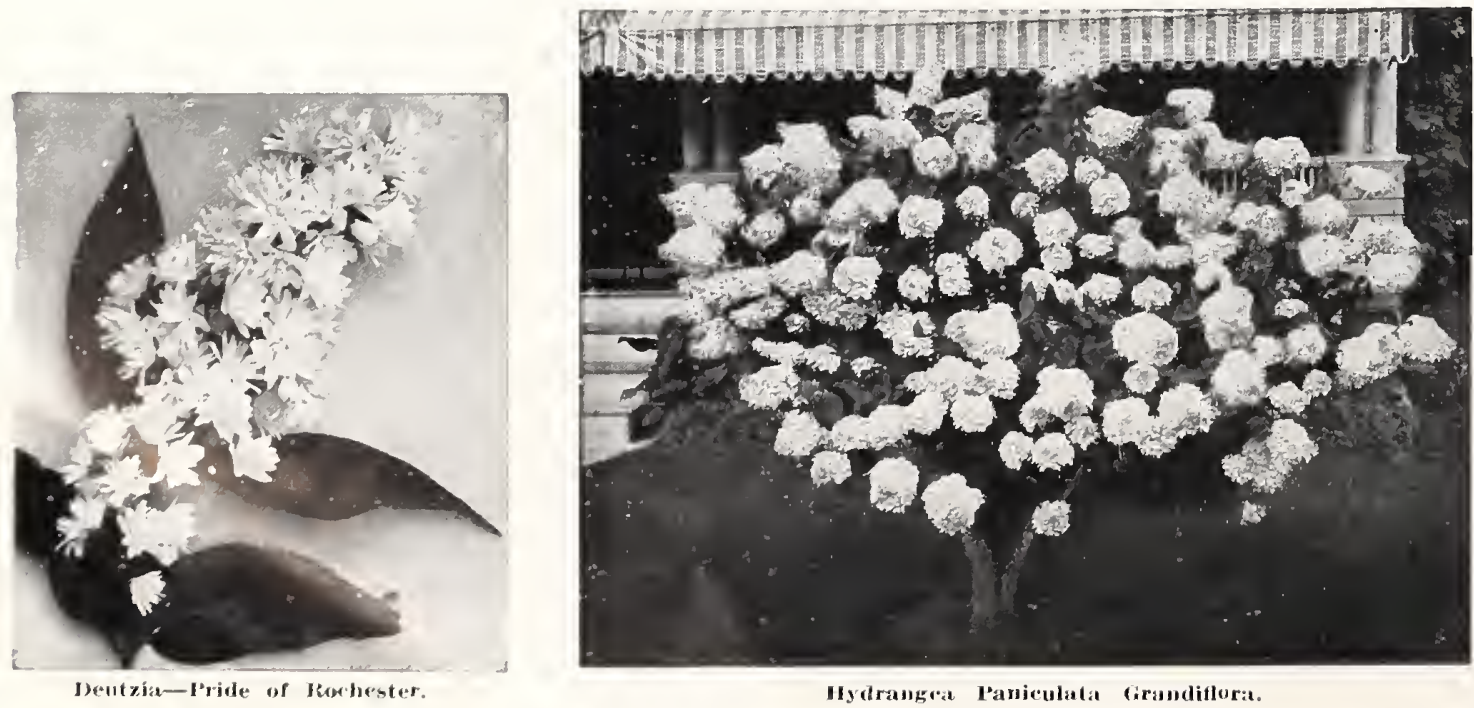

Hydrangea Paniculata Grundiflora.

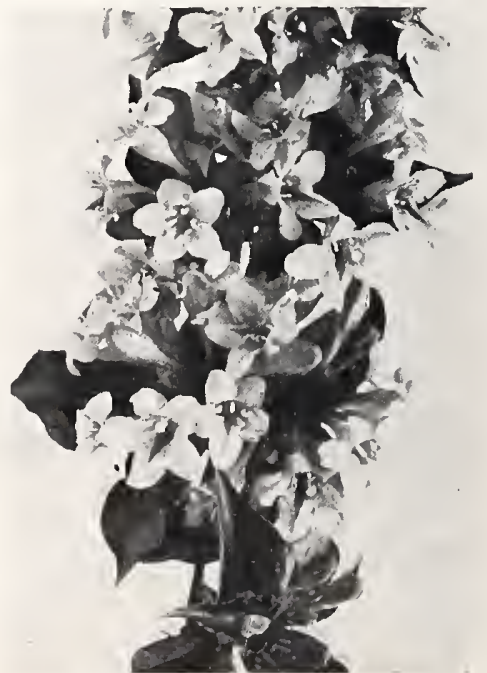

Weigela, Eva Rathke. 


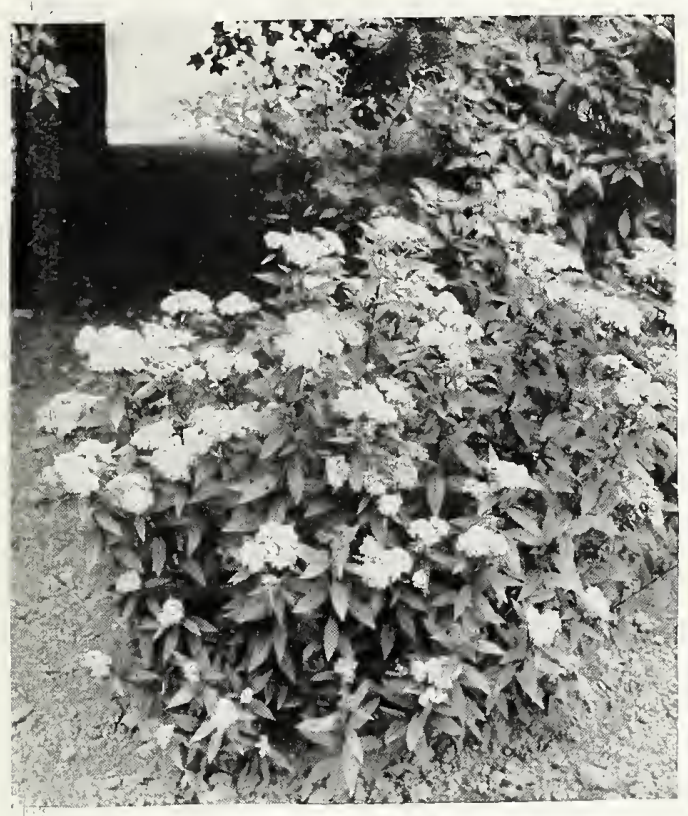

Spirca Anthony Waterer.

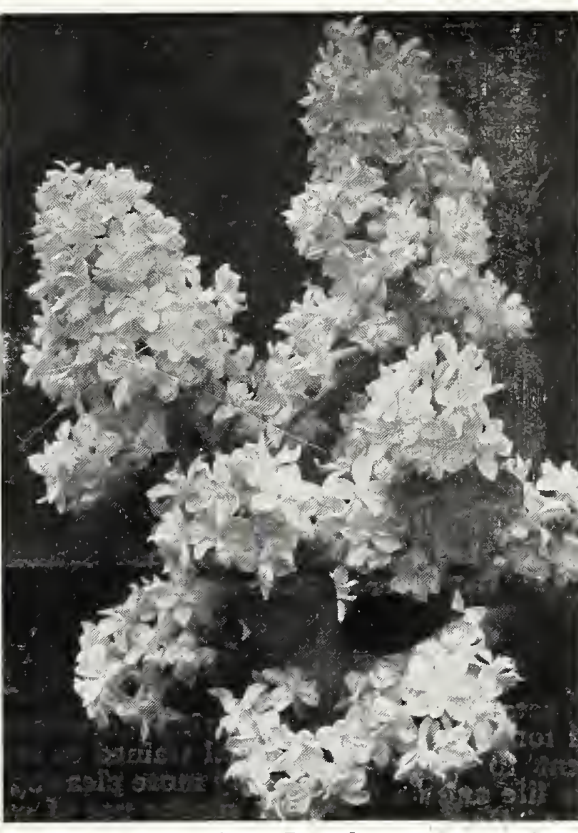

Lilac. Iemolne.

UPRIGHT HONEYSUCKLES. Make very desirable and attractive PHILADELshrubs, with bright flowers followed by showy berries in the fall. Va- PHUS: FOI.IIS

Fragrantissima. Small pink and white fragrant flowers appearing early in the spring, before the leaves.

Grandiflora Rosea. Bright pink flowers.

Morrowii. Pure white flowers, followed by bright red fruit

Pink Tartarian. Pink flowers in June.

White Tartarian. Creamy white, very fragrant flowers

Ruprechtiana. Fine variety with showy white flowers, and valuable for its showy red fruit.

KERRIA JAPONICA (Globe Flower). Orange yellow double flowers. Handsome. Price, $75 \mathrm{c}$ each.

KERRIA VARIEGATED. Small green foliage, edged with white, A pretty dwarf shrub, with a profusion of bright yellow flowers. Price,
$75 \mathrm{c}$ each.

LILAC, Purple. Bluish purple flowers. Standard variety; always good. Price, $75 \mathrm{c}$ each.

LILAC, White. Cream-colored flowers; very fine. Price, $75 \mathrm{c}$ each.

LILAC, Charles X. Large, shining leaves; flowers large, single, reddish purple. Price, $\$ 1.00$ each.

LILAC, Lemoine. A choice variety, bearing large clusters of double white flowers. Price, $\$ 1.00$ each.

LILAC, Ludwig Spaeth. New, and believed to be the finest of the class. Color, purplish red. Price, $\$ 1.00$ each.

LILAC, Pres. Grevy. Very large blue flowers; largest of all. Price, $\$ 1.00$ each

PHILADELPHUS VIRGINALIS. (New). One of the most beautiful new varieties. Flowers pure white, sweetly scented, often as large as a silver dollar. Blooms in June and continues over a long period. A cluster of bloom resembles a bride's bouquet of orange blossoms. Price, $\$ 1.00$ each or $\$ 9.00$ per 10 .

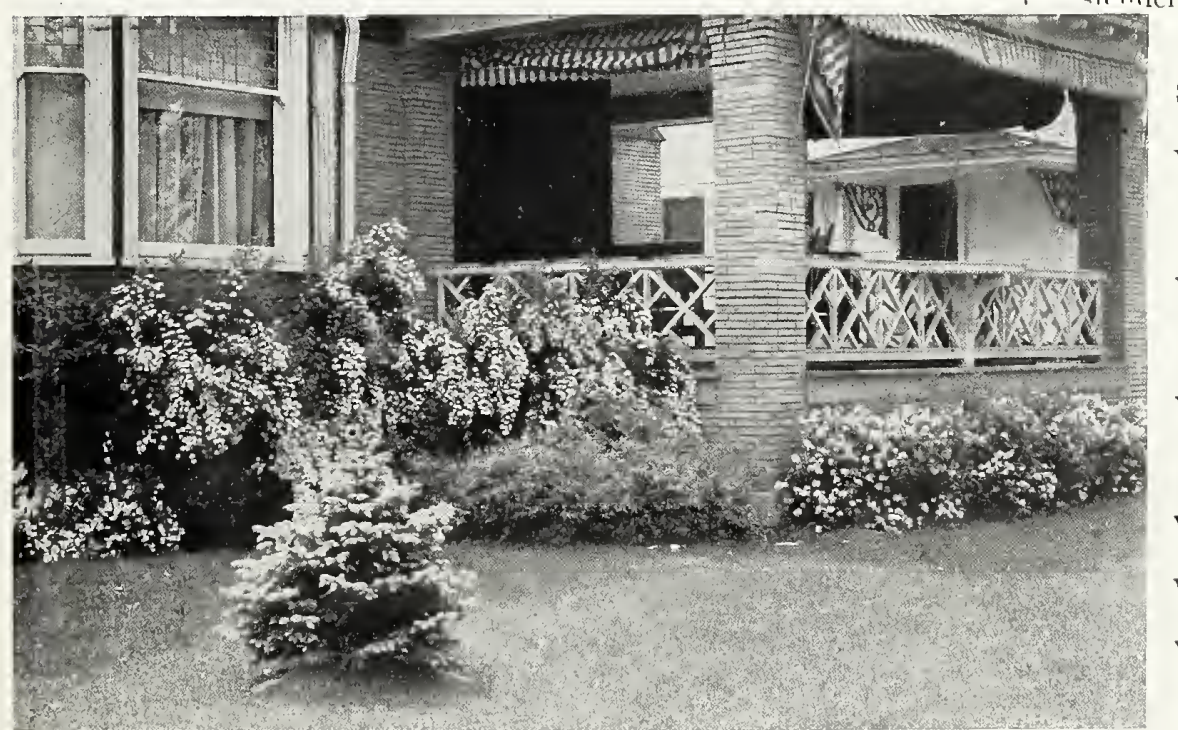

A very modest porch planting-this planting consists of twenty-seven shrubs and one

evergreen; began to bloom May $g$ and continued to flower lor a period of eight wetks.
A U R E U S

(Golden Sy

ringa:) The leaved shrub. each.

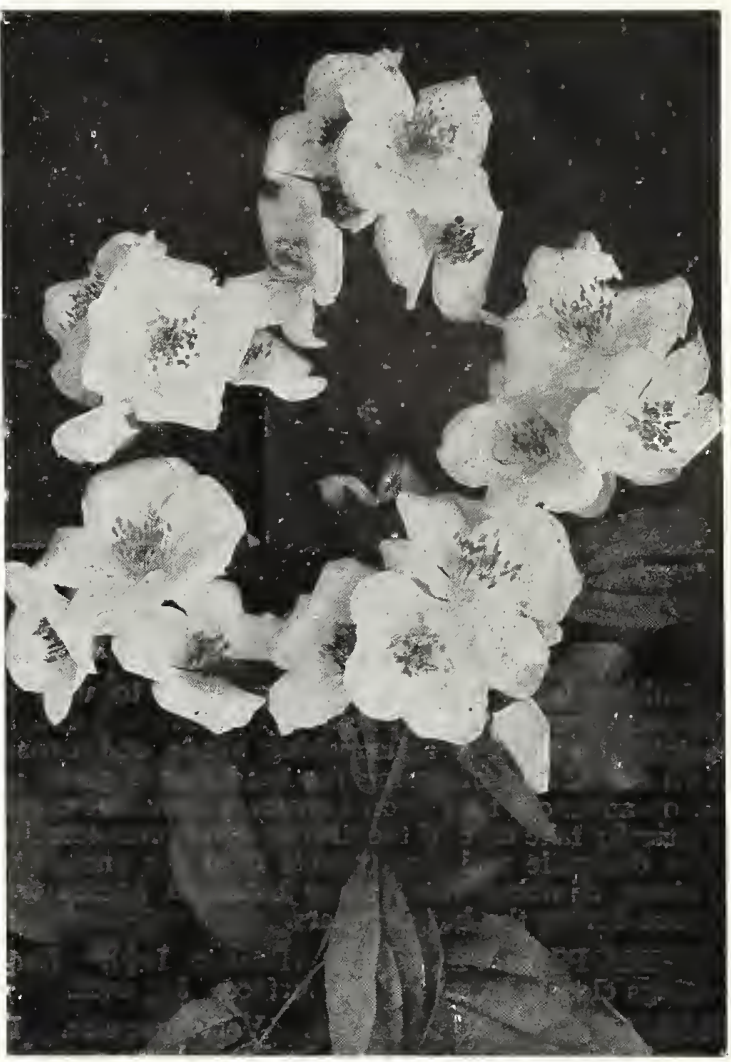

Philadelphus Virginalis.
PHILADELPHUS CORONARIUS (Common Syringa or Mock OrPHILADELPHUS, MONT BLANC. A charming variety, of dwarf habit, with very large, pure white, fragrant flowers produced in great andance slender, upright branches. Price, $\$ 1.00$ each

QUINCE, JAPANESE SCARLET (Cydonia Japonica). One of the best hardy shrubs. Covered with brilliant scarlet flowers early in SYMPHORICARPOS RACEMOSUS

mental hardy shrub. Small pink flowers, followed by laroe, waxy SYMPHORICARPOS VULGARIS (Coral Berry). Vigorous, quick shrub, similar to Sinowberry except its fruit is red.

SPIREA, Anthony Waterer. New, dwarf-growing variety, crimson flowers, blooms all season. Useful in foundation plantings in front of other shrubs. Price, $75 \mathrm{c}$ each.

Prunifolia (Bridal Wreath). white flowers in May. Leaves turn to beautiful orange. Price, 75c each.

SPIREA Thunbergii. Dwarf growing shrub of graceful form; ing a light feathery appearance. Pure white flowers,

very early 111 the spring.

SPIREA, Van Houttei. Grandest of all. A fountain of VIBURNUM PLICATUM. (Japan Snowball). Completely

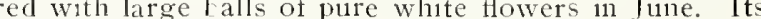
dark plicated foliage and massive clusters of bloom are not equalled by any other shrub. Price, $\$ 1.00$ each.

VIBURNUM OPULUS STERILE. (Common Snowball or Guelder Rose). An old-time favorite, without doubt one of the best flowering slirflice, $75 \mathrm{c}$ each.

VIBURNUM OPULUS. (High Bush Cranberry). Very fower, and berries are scarlet and hang on well into spring. Price, 75c each.

WEIGELA Candida. Pure whi

Price, $75 \mathrm{c}$ each.

WEIGELA Rosea. Rose-colored flowers in May and June Price, $75 \mathrm{c}$ each.

WEIGELA, Variegated Leaved.

Price, $75 \mathrm{c}$ each.

WEIGELA, Eva Rathke. Charming new variety. Brilliant crimson flowers twice in one season. Price, $\$ 1.00$ each. 


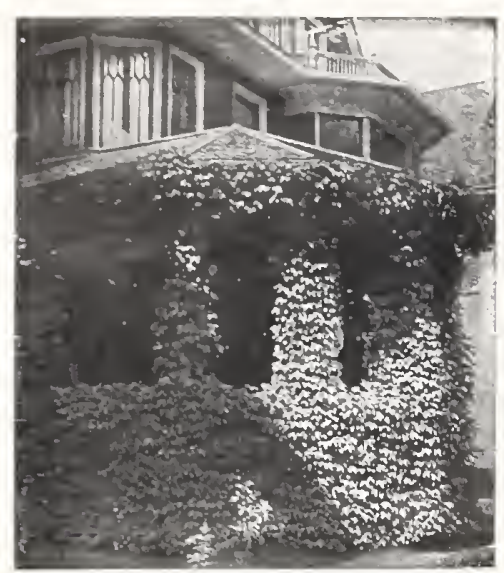

\section{Climbing Vines} The hardy vine is best adapted for covering an With they soon become a beautiful covering. Hardy vines nore desirable and less trouble than the annual or tender varieties. picture during the hot summer.

AMPELOPSIS VEITCHII (Boston Ivy). Requires no support, closely to smoothest surface. 50c each.

CLEMATIS PANICULATA. Very popular. Blooms profusely; small, singte, white flowers borne in large panicles. 50c each.

CLEMATIS HENRYI. Finest white Clematis. Flowers very large; single. $\$ 1.00$ each.

CLEMATIS JACKMANNII. Best purple sort. Single, very large. $\$ 1.00$ each.

CLEMATIS, MAD. ED. ANDRE. Distinct and fine. Flowers deep $\$ 1.00$ each.

CLEMATIS, RAMONA. (New). Deep sky blue, distinct from any other kind; very attractive. Extremely hardy. \$1.00 each.

DUTCHMAN'S PIPE. Large, heart-shaped leaves. Brownish flowers resembling small pipe. Hardy, rapid grower. $\$ 1.50$ each.

EUONYMUS RADICANS VEGETUS. (Evergreen Bittersweet). Very dense-growing, trailing vine, covered the whole year with green foliage. $75 \mathrm{c}$ each.

HONEYSUCKLE, HALL'S JAPAN. Almost evergreen. Covered from Jilly to December with fragrant white flowers, turning to yellow. 50 c each.

WISTARIA, Purple. Perfectly hardy; very beautiful. Flowers in sting in long, drooping racemes. 75c each.

WISTARIA, White. A very beautiful and choice variety, with pure $\$ 1.00$ each.

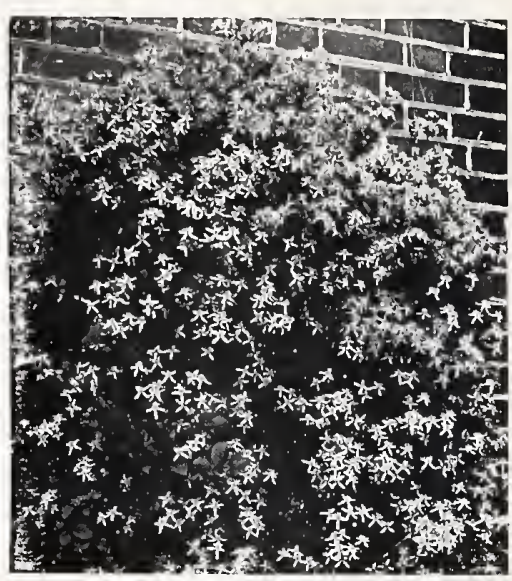

Clematis Paniculata.

\section{Hedge Plants}

A living fence-one made of plants, attractive with their green leaves, ormal trained or arched branches, colored foliage or bright lerries is surely more pleasing than the still, rigid, mechanical effect obtained by he similar use of wood or metal. A lawn hedge is permanent-once lanted, only occasional pruning or shearing is required.

3ARBERRY, THUNBERGII (Japan Barberry). Brilliant green foli age, turning to most glorving colors from autumn to December Loaded with scarlet-crimson berries after leaves fall. Hardy where Privet is not. One of the best shrubs to plant against the foundations of a house or in front of taller growing shrubs, 12 to 18 inches, $\$ 35.00$ per $100 ; 18$ to 24 inches, $\$ 45.00$ per 100 . Extra strong 3 -year plants for planting as shrubs or for screen in front of porches, $60 \mathrm{c}$ each.

BOX-BARBERRY. The new hardy dwarf hedge and border plant. A dwarf form of the popular Barberry Thunbergii; equally as sturdy, hardy and dependable, varying from it only in its dwarfer, compact and upright habit of growth. Excellent for low edging for ormal gardens when set four to six inches apart and kept trimmed. Also makes a beautiful low hedge when set 6 to 12 inches apart. Price, strong, 2-year plants, $\$ 4.00$ per $10 ; \$ 30.00$ per 100 .

CALIFORNIA PRIVET. Most popular half-evergreen hedge. Remarkably beautiful, glossy, dark green foliage; strong, rapid grower. It transplants easily, grows quickly, making a hedge the first year. and succeeds in almost any soil. The plants should be set about 1 toot apart and cut to 3 or 4 inches above the ground after planting to make the hedge bushy at the bottom. 12 to 18 inches, $\$ 5.00$ per $100 ; 18$ to 24 inches, $\$ 7.00$ per $100 ; 2$ to 3 feet, $\$ 10.00$ per 100 .

AMOOR RIVER NOF'TH PRIVET. Similar to California Privet, but hardier. A valuable ornamental slirub for hedges and borders in cold and exposed places. Fine upright growth, glossy green foliage. Its pure white flowers appear in Jume and are followed by bluish black seeds. 18 to 24 inches, $\$ 15.00$ per 100 .

Other desirable hedge plants, American Arbor-Vitae and Norway Spruce, Altheas, Hydrangeas, Spireas, Philadelphus.. (See descriptions under Evergreens and Shrubs.)

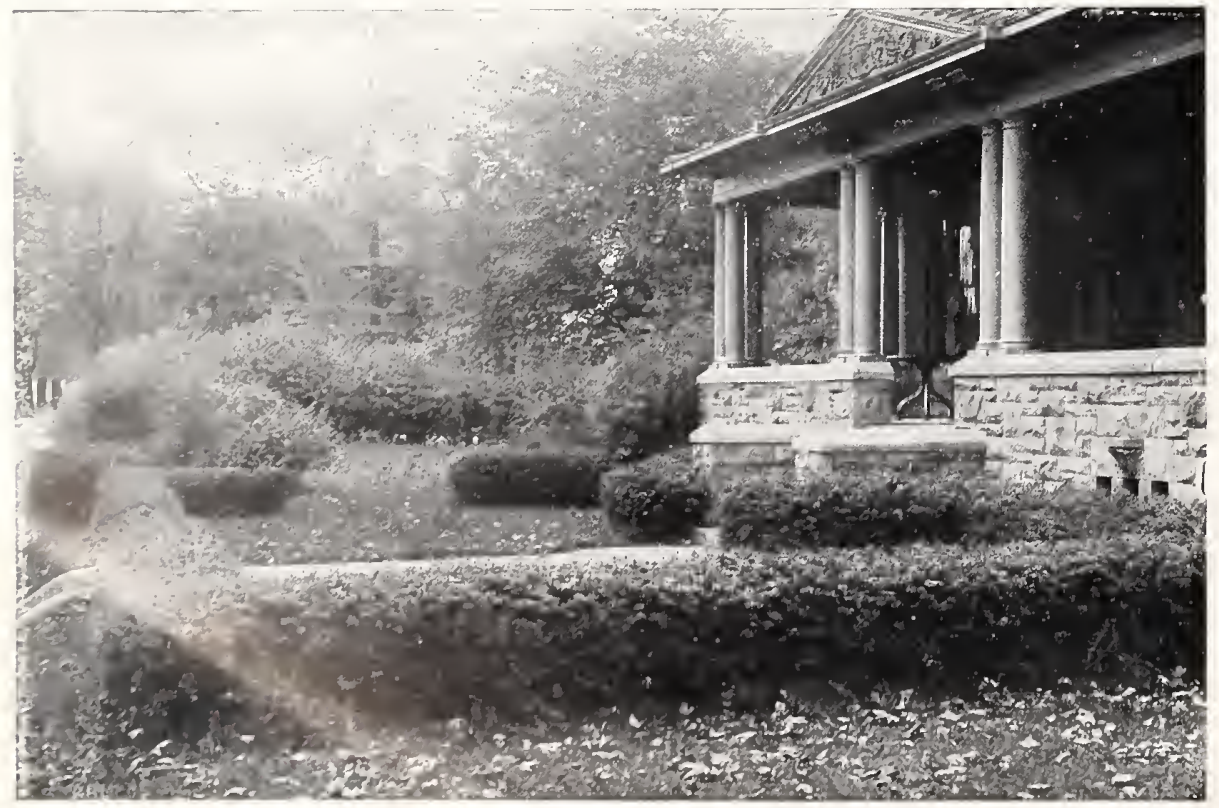

Barberry IIeize.

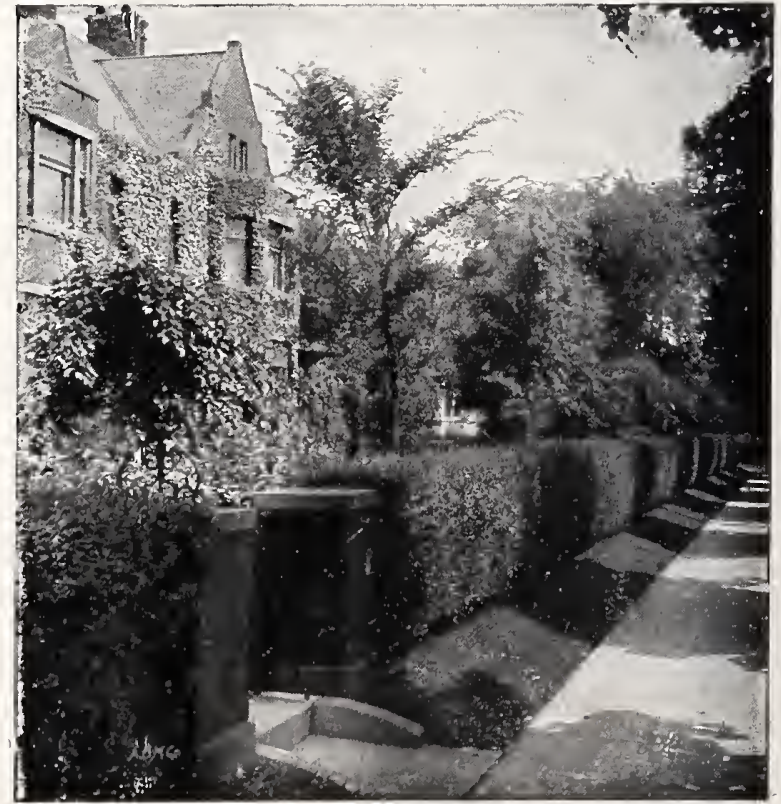

California Privet. 


\section{The Peonies}

\section{Rival the Rose in Perfection of Bloom}

Fine, hardy plants, rivaling the rose in perfection of bloom and coloring, requiring little extra care, as they thrive well in any soil. Our list of varieties has been made up with great care to include only the best and mo-t distinct kinds. We give you sorts that are really worth while, presenting a wide range of color and shade, coming into bloom throughout the season. Prices are for divisions with three to five eyes, and good roots.

CHARLEMAGNE. Creamy white, center light lilac, flesh shaded with chamois. Large, globular, very compact. Late. $60 \mathrm{c}$ each.

COURONNE D'OR. Immense, very full, ball-shaped bloom?, snowy white with yellowish stamens. Fragrant, perfect cut flower sort, very late, comes in after all other longstemmed whites are gone. $75 \mathrm{c}$ each.

DELACHEI. Deep crimson pur ple, one of the best dark sorts. Late mid-season. 60c each.

EDULIS SUPERBA. One of the best early varieties. Large, loose, flat crown, bright mauve pink. 75c each.

FELIX CROUSSE. Brilliant, flaming red. By far the best red; very popular with florists. Late mid-season. \$1.00 each.

FESTIVA MAXIMA. Very large, a well known and almost perfect peony. High built flowers on long stems, pure white with inner fetals ideal early white. 75c each.

FRANCOIS ORTEGAT. Semidouble, large rurplish crim son bloom with brilliant goldstriking. 60c each.

LA TULIPE. Late; very large, full, shell formed blooms on long.

erect stems. Delicate rose, fading to creamy white. One of the

best. 63c each.

LIVINGSTONE. (True Crousse Variety). Soft rosy pink, with silvery reflex. Large, comract, rose type, with tall, very strong stems. Best late pink. $\$ 1.00$ each.

MADAME CALOT. A grand

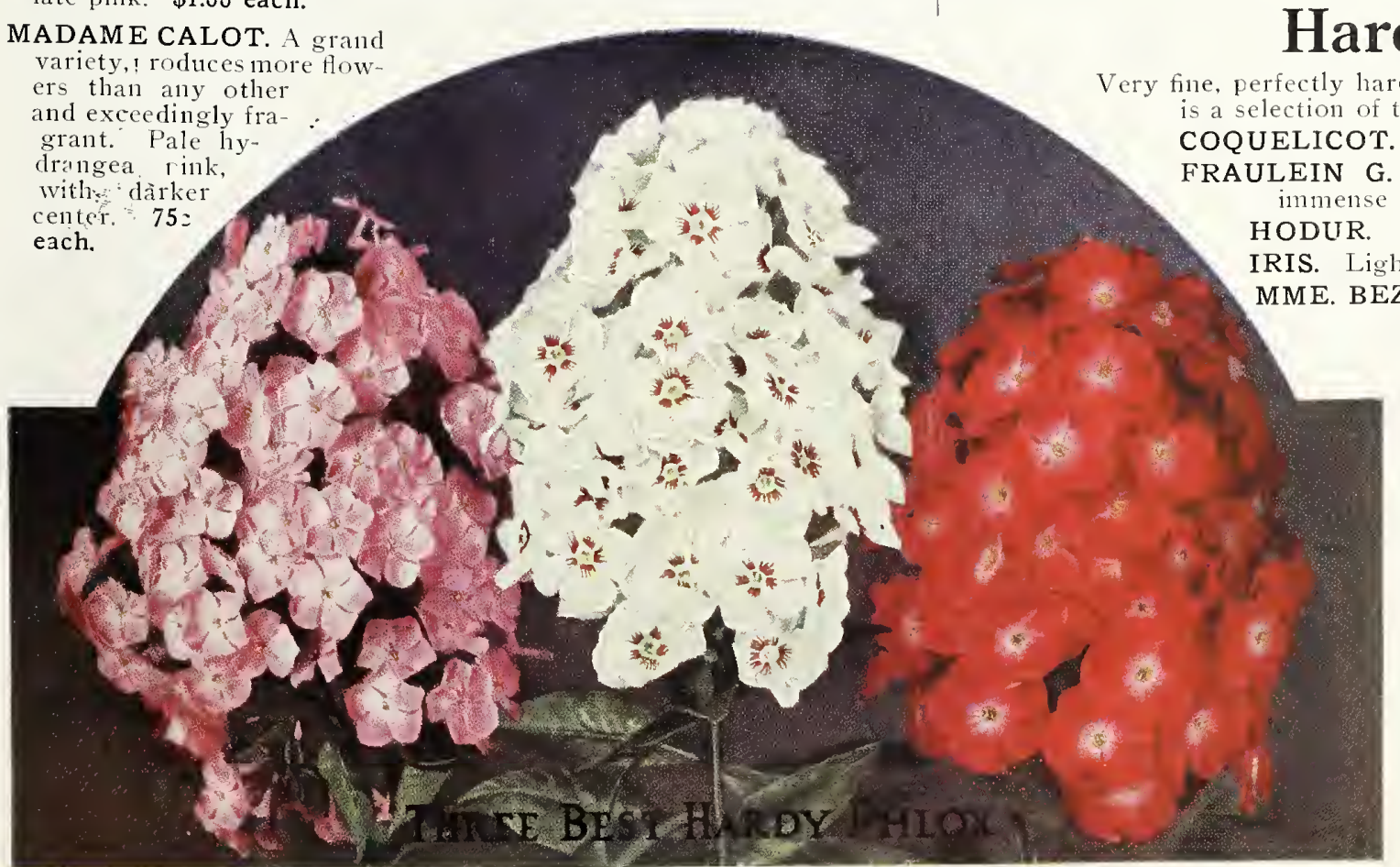

GFICINALIS RUBRA PLENA.
Grandmotlier's garden. 75c each.

ROSEA SUPERBA. Brilliant deep cerise pink, compact, perfectly formed blooms on long stems. Keeps well. Midseason. 75c each.

\section{Hardy Phlox}

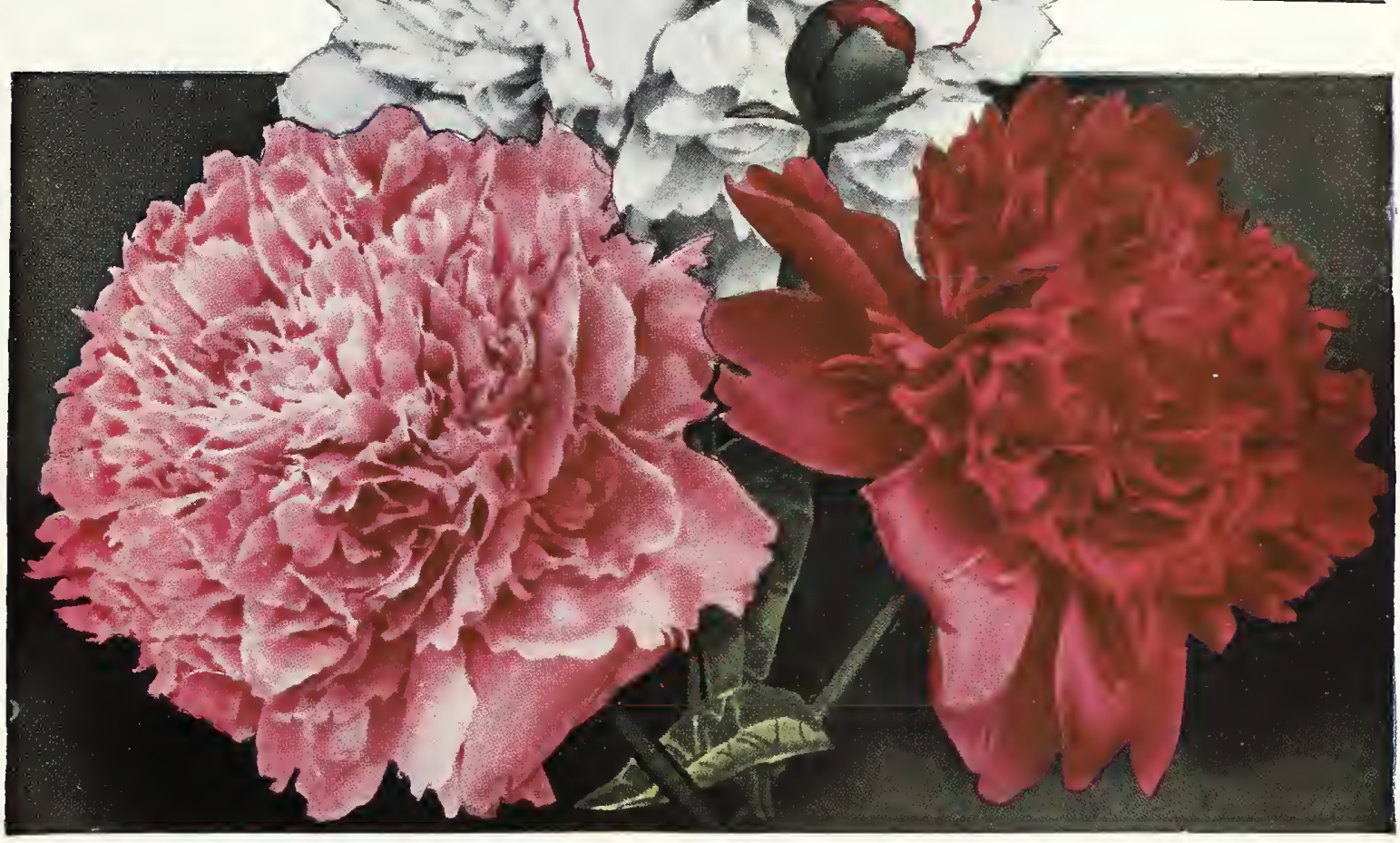

Cestiva Maxima.

Felix Crousse 


\section{Evergreens}

ABIES (Fir) Balsam. Very hardy: rapid, slender grower, foliage silvery under-

E feet, $\$ 2.50$ each; 3 feet, $\$ 3.50$ each.

Concolor or Silver Fir. One of the hardiest and most beatutiful evergreens.

Graceful habit, broad, handsome foliage, bluish above, silvery underneath.

2 feet, $\$ 5.0$ J each; 3 feet, $\$ 7.50$ each.

JUNIPER, Irish. A distinct and heantiful variety, forming a neat tanering

年

$\$ 1.50$ each; 3 feet, $\$ 2.50$ each.

Savin's. Prostrate, st reading loranches, with somber grcen foliage. Hardy, $\$ 4.00$ each

Virginiana (Red Cedar) A tall growing native of great heauty. Tapering form, bright, rich green foliage. 2 feet, $\$ 2.50$ each: 3 feet, $\$ 3.50$ each.

Virginiana Glauca (Blue Cedar). Probably the best variety of Cedar. a fav thery-blue foliage. 2 feet, $\$ 4.00$ each; 3 feet, $\$ 6 . c 0$ each.

PICEA (S1 ruce). Excelsa (Norway Sr ruce.) The most generally used of ever-

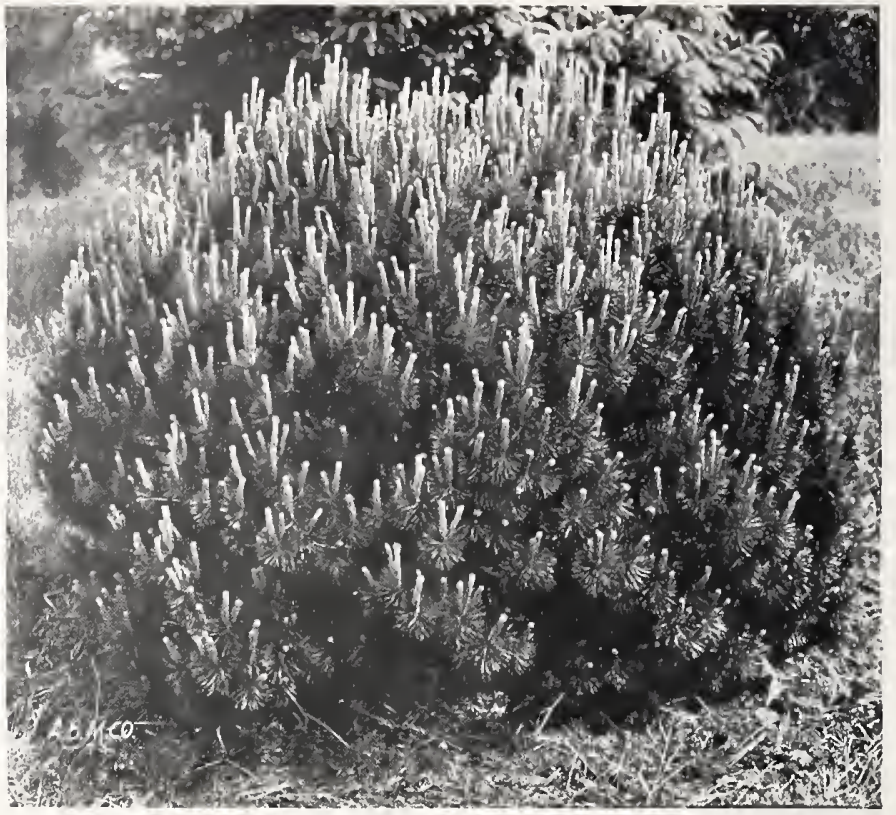

Dwatf, or Mugho Pine.

One of the lest for hedges and windbreaks. $2 \mathrm{ft}$., $\$ 1.50$ each; $3 \mathrm{ft}$., $\$ 2.50$ each; $4 \mathrm{ft.}, \$ 3.50$ each.

Pungens Glauca (Colorado Blue Spruce). Hardy and beautiful, of ryramiclal form. foliage rich blue or sage color. $2 \mathrm{ft}$. $\$ 7.00$ each; $3 \mathrm{ft.}, \$ 10.00 \mathrm{each}$.

Pungens Kosteriana (Koster's Grafted Blue Spruce), The highest colored most strikingly beautiful of all evergreens for the lawn. Perfectly shaped glistening blue. 3 feet, $\$ 15.00$ each.

PINUS (Pine). Austrian or Black Pine. A robust grower with leng, dark, stiff needles. Does well on all soils. 2 feet, $\$ 2.50$ each; 3 feet, $\$ 3.50$ each.

Sylvestris (Scotch Pine). A rapid grower with strong 1 ranches and short stiff bluish-green foliage 2 feet, $\$ 2.50$ each; 3 feet, $\$ 3.50$ each.

Mughus (Dwarf Mugho Pine). Of low. dense, spreading growth, with very lark green foliage. Very hardy and suitable for covering slopes. 18 inch spread, $\$ 4.00$ each.

RETINISPORA (Japanese Cedar). Plumosa. A graceful tree with plume-like dark green foliage. Responds to pruning, rarticularly useful for hedges and

mass plantings. $2 \mathrm{ft}$., $\$ 3.50$ each; $3 \mathrm{ft}$., $\$ 5.00$ each.

Plumosa Aurea. Bright golden foliage, retains its color all summer. Very distinct and beantiful. 2 feet, $\$ 3.50$ eash; 3 fee,$\$ 5.00$ ear b.

THUYA (Arbor-Vitae). Occidentalis (American Arbor-Vitae). Very largely 1sed, and perfectly hardy. A low-branched. bushy pyramid, foliage bright green above, yellowish beneath. Useful to

Globcsa. Low, thick, globe form. Very desirable. 11/2 feet, $\$ 2.50$ each.

Geo. Peabody's Golden. Dwarf, dense-growing variety, holding its golden yel-

low color all summer. 2 feet, $\$ 3.00$ each.

Pyramidalis. A valuable upright evergreen of dense, compact habit. Foliage light green. 2 feet, $\$ 2.00$ each; 3 feet, $\$ 3.00$ each.

Sibirica (Siberian Arbor-Vitae). Large, dark oreen foliage, strong, pyramidal growth, very gond and hardy. $2 \mathrm{ft}$., $\$ 2.50$ each; $3 \mathrm{ft}$., $\$ 4.00$ each.

TSUGA (Hemlock). Canadensis (Hemlock Spruce) Remarkably graceful and beautiful native tree, with drooping branches nther trees. Very useful for hedge planteach; 3 feet, $\$ 4.00$ each.

\section{TAXUS CANADENSIS}

13 to 24 inches spread, $\$ 3.00$ eash.

TAXUS CAPITATA (Upright Japan Yew).

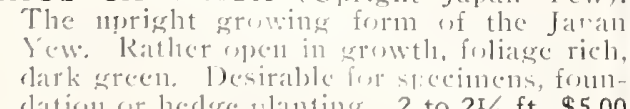
each.
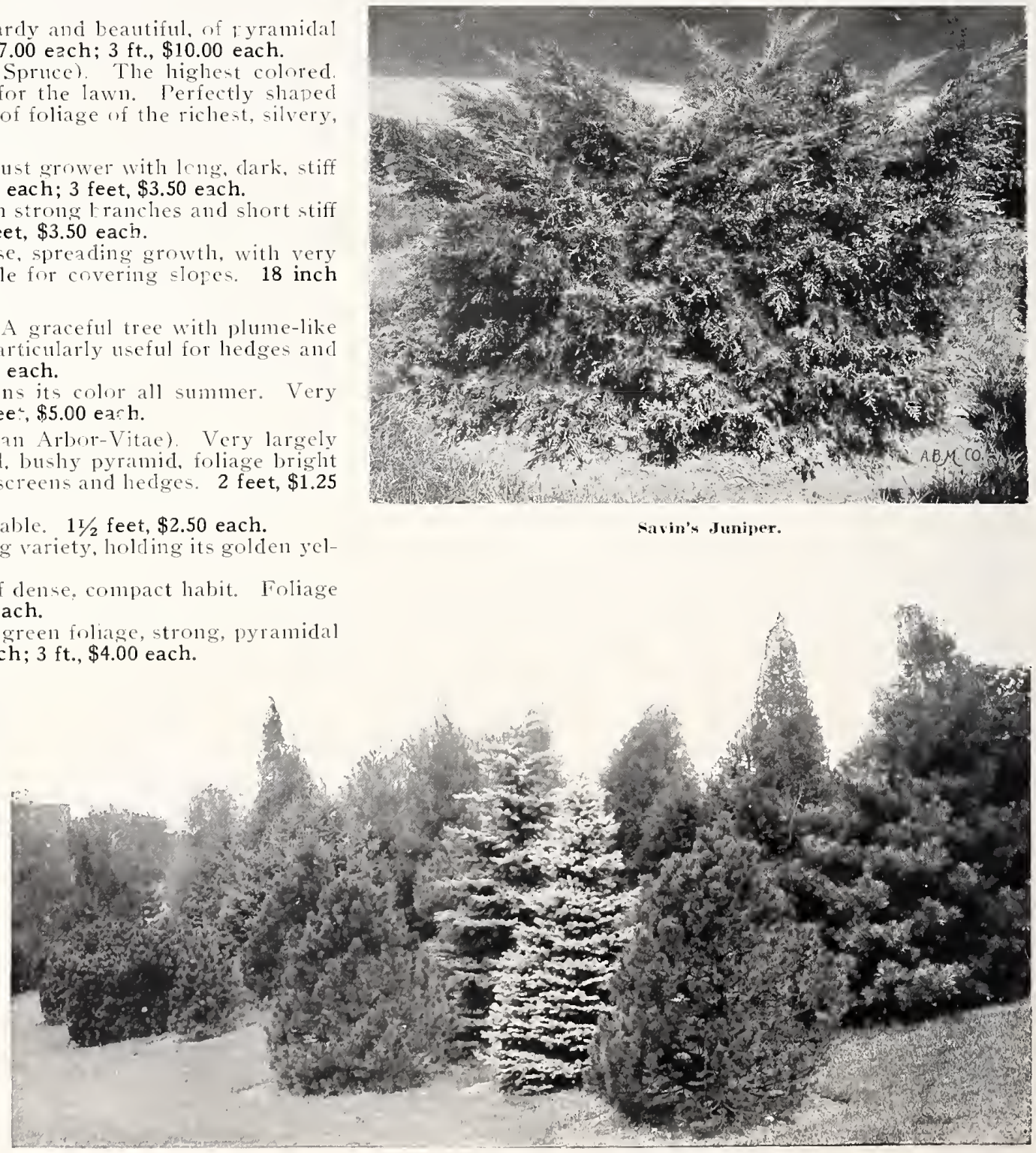

Savin's Juniper. 


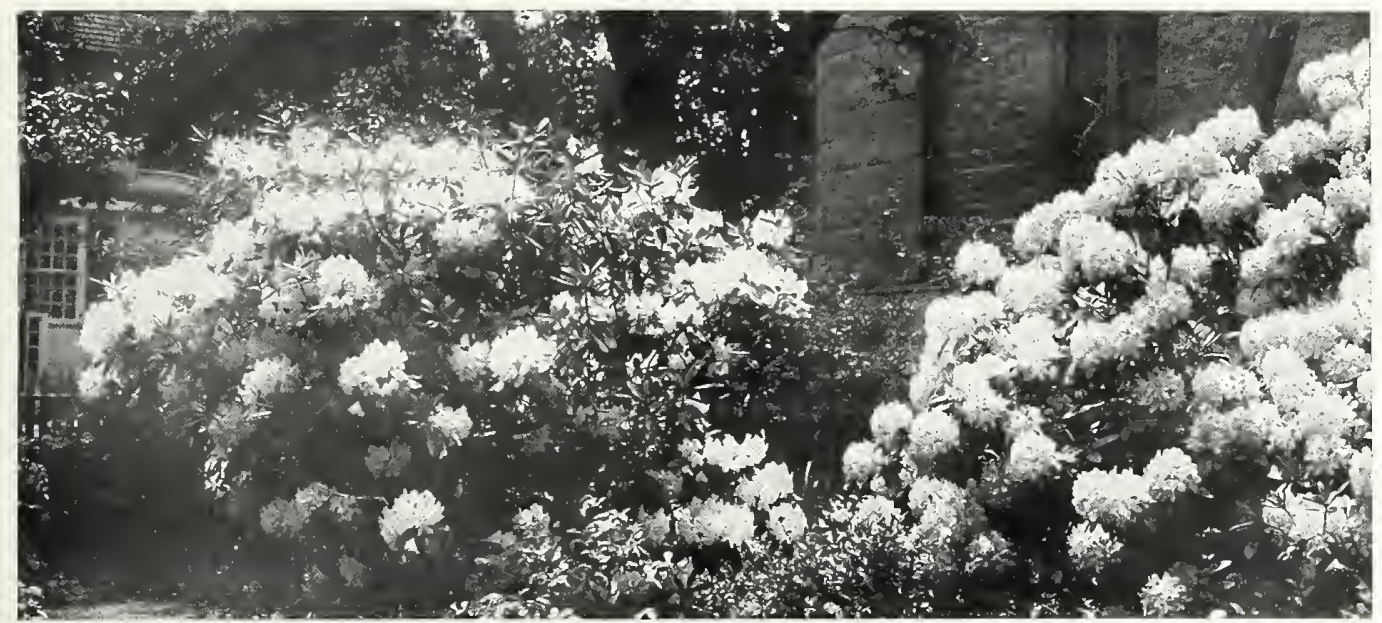

Evergreen Shrubs

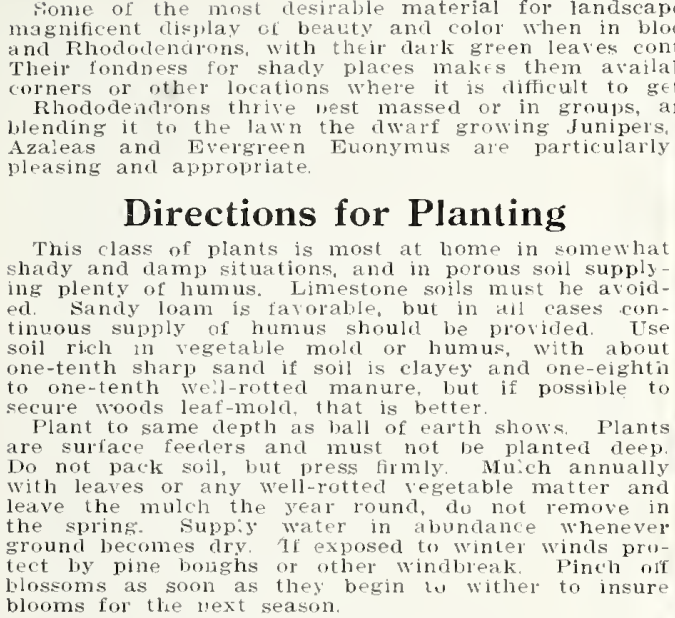

\section{Rhododendrons}

Carolinianum (Carolina Rhododendron). Native. Host heautiful of American Rhodoprofusion, their color being a beantiful pink This variety will stand exposed locations and is perfectly hardy, thriving in either sun or shade. 2 to 3 foot clumps.
$\$ 35.00$ per $10 ; \$ 300.00$ per 100 .

Catawbiense. Native. Flowers a bright rosepurple, borne in large clusters at the ends of the branches. Perfectly hardy in northern latitudes and one of our very finest broad-leaved evergreens. 2 to 3 foot clumps, $\$ 4.00$ each; $\$ 35.00$ per $10 ; \$ 300.00$ per 100 .

Maximum (Great Laure1). Native. A variety commonly used for mass and wondland plantings. Flowers white to pink. Blooms later than other American species, the ilowers appearing in July. Grows naturally from Canada south. 2 to 3 foot clumps, $\$ 3.00$ each; $\$ 25.00$ per $10 ; \$ 200.00$ per 100.

\section{Tree or Standard Roses}

PRICE: $\$ 2.50$ each, or $\$ 20.00$ per 10 .

Novel and beautiful plants. Budded on single upright stems or hardy Rugosa stock 3 to $5 \mathrm{ft}$. high, which reveals all the foliage and all the bloom in a rounded clump at the rop. Lnique effect: are produced by planting in groups or as border lines by garden walls. Indispensable in rose and foner gardens to relieve the flat appearance and give th dividuality

We offer the following varieties; for description of bloom see same Theties under Roses:

Climbing Imerican Beauty

Dolothy Perlin

Paul's Scaullex Climber

Tausendechot un

Columbia

Fran IEIl] Druschli

Gruss an Teplity

Paul Neyrou
Jomlineer J. L. Mock

Lamrent Carle

Mrs. Iaron Ward

Oplelia

liadiance

Sumbure

White lisllatrey

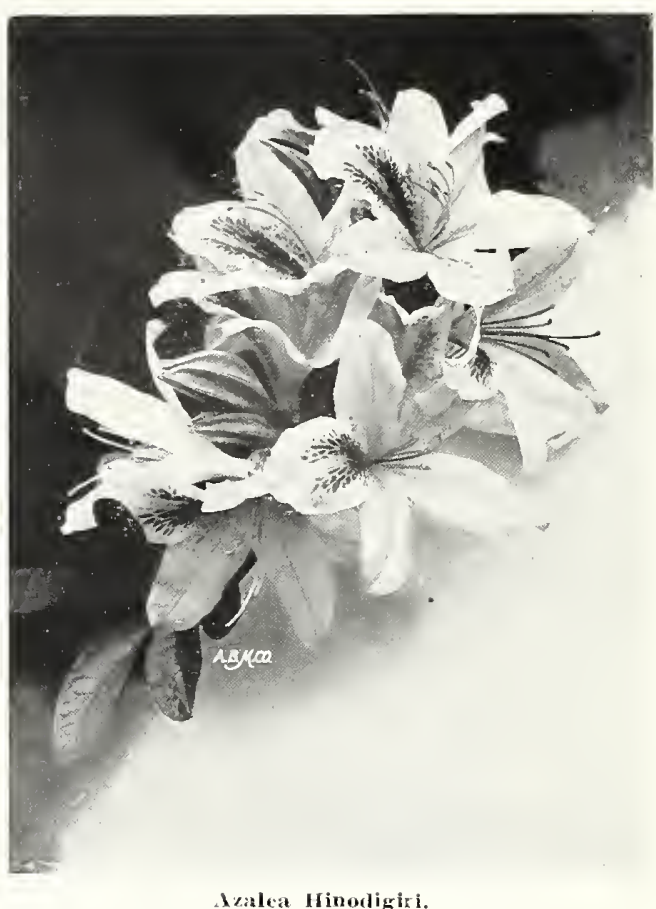

Azaleas

Amcena. Hardy Evergreen Azalea. A low. Lushy shrub with small green leaves chang ing in winter to a rich bronze or coppery brown. In spring the whole plant is covered continue to open for a period of 2 or 3 weeks. 15 to 18 inch, $\$ 3.00$ eacis.

Lutea (calendulacea). Flanc-colored Azalea. Ranging from flame color through shades of red and yellow, remaining in bloom for to 8 feet high. 15 to 18 inch, $\$ 2.50$ each: $\$ 22.50$ per 10 .

Hinodigiri. A compact growing variety, with beautiful, cvergreen foliage and brilliant 12 to 15 inch, $\$ 3.50$ each.

\section{Kalmia}

Latifolia (Calico Bush; Mountain Laurel). Na An evergreen shrub, growing luxuri antly along our mountain sides, forming

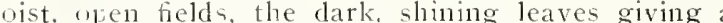
brightness to the landscape. In Nlay and June the gorgeous coloring of the large rose or white flowers lends an enchantment to the picture that one will not soon forget. It is of easy.culture in almost per 100

WRITE FOR SPECIAL PRICE ON CAR LOADS AND LARGER SIZES OF RHODODENDRONS AND KALMIA.

\section{Dwarf Polyantha Roses}

Very popular for bedding purposes and for edging borders of shrubs roses or perennials they have no equal. Splendid, hardy, showy and compact bushy specimens about 1 inches high, producing immense continue in full bloom through a remarkably long season. Price, $\$ 1.00$ each: \$9.00 per 10.

B.MBY R.MBLEL. The orjginal dwarf form of Crimson Rambler. The Tronderful persistency of its bloom makes it one of the choicest plants in cultivation.

B.IBY TIUSENDSCHOEN. Dwarf bushy ginth: flowers large semi double, in pretty clusters; a prevailing flesh-pinl color. Flowers

B.NPY DORotuy (Pink Baby Rambler). A delightful ilower of bright pink. Blooms in masses like the climbing Dorothy Perlin

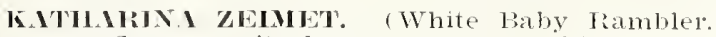

rose, flowers tuite large, a creamy white in color, and trath branch

bears from 15 to 20 of then. 


\section{Roses}

Strong :-ycall fichil oroun plauts. The lore of the Those is unirersal, and with

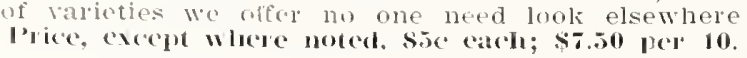

\section{Superb Everblooming Roses}

IIIBOy II III. Geatiful rich rellow, ehanging to pinkish fawn.

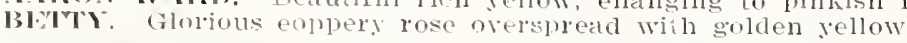

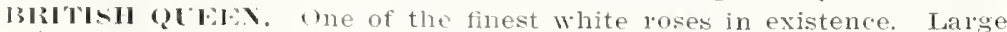

s of $\mathrm{T}$

COIIII3I. The of the finest now loses. Lovely shade of pink, shading deeper at center. Strong sower, almost tholness. Very free bloomer, and fragrant, 1.00 cilcll.

clitsilli. A new free flowering red Rose that is a wonder. Beautifully formed big and double blooms of rieh, velvety erimson. si.00 each

l) IX Hold Gorgeous silvery carmine. shaded salmon.

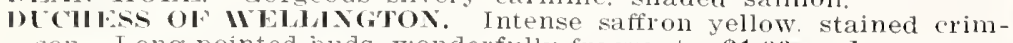
( Monderfully fragrant. \$1.00 each.

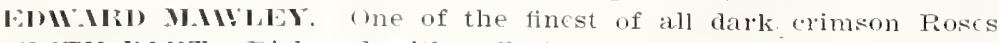
ISITII IXIRT. Rich red with suffusion of deep salnon and coppery

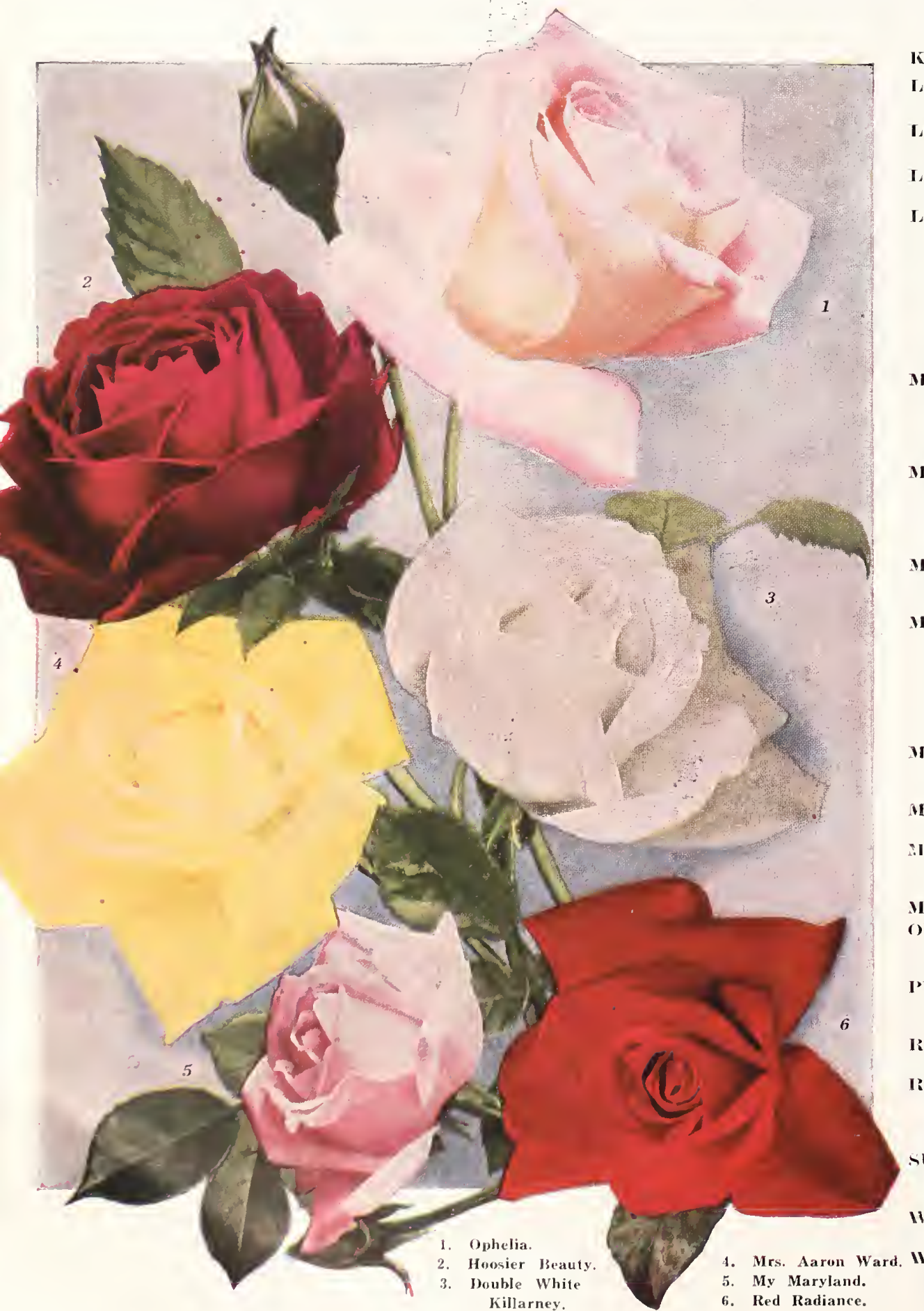

TRANCIS SCO'T IET. A glorious liose. Ferfectly formed bud opening into blizing red flowers of largest size, full and double, very fragrant, Strong, healthy grower, hardy cverywhere

GOLDIX OPIICII. A raluable new yellow garden riost, unusually tree flowering. Sturdy, stiff-stemmed grower with beautiful glossy foliage. Fragrant, medium sized flowers from beautifully formed buds. Tich apricot yellow, slightly paler at edges, \$1.00 cach.

GOIRGOIs. Flowers large and full. Deep orange-yellow, heavily veined with reddish eopper. One of the most striking lioss in existence, delightfully fragrant. \$1.00 cich.

GRISS IN TLPLIT. Brilliant searlet, shading to velvety crinson. HMDEY. Rieh velvety crimson. Large double, intensely fiagrant. IIOS'SII: BWIUT: Glowing erimson-scarlet with darker shadings Large and double, with velvety petals. A magnificent blowm of dazzling brillianee and delicious fragrance.

JONKHIER J. L. MOCK. Giant pink Rose.

k. MSIRIN ITGOSTI ITCOORi. Soft, pearly white, shading to cramy yellow. Very double, of exquisite formation. Fragrant.

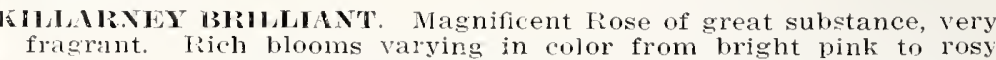
carmine. I ndoubtedly best of the Killaney type. Same hatit of growth and freedom of bloom, but flowers nore double and more brilliant. \$1.00 eaclı.

KILIMRNIY. Brilliant, sparkling pink. Very hardy.

IAIIY IIJCE STINLWY. Shell-shaped outside petals of deep coral rose, inside pale fiesh. Large, fragrant.

WII) HIIINGDON. Benutiful apricot yellow shaded to orange.

I. ILIST C.RLE. A large, billiant, velvety earmine liose of perfect form and incense fragranee.

IOS NGRLES. A magnificent Rose of enormous size. Color a luminous flame pink, toned with eoral and shaded with translueent gold at the base of the petals. Fragrant as Ameriean Beauty. Buds long and pointed, expanding into flowers of mammoth proportions. Vigorous grower. By all admitted to be one of the finest Roses ever introduced. Beauty of form and ever-increasing wealth of eolor are maintained until the last petals fall. \$1.00 each.

MADNM BUTTERFIS. A glorified Ophelia; bud larger, eolor tints greatly intensified; a harmony of bright pink, aprieot and gold. Perfect in form and texture, deliciously fragrant. Foliage and habit unsurpassed. \$1.00 cacl.

MADAM EDOUARI) HERRIOT (Daily Mail Ros(o). Artists have raved over this variety. Gorgeous combination of terra eotta and bronze with flame shadings, almost impossible to deseribe. Foliage bright and glossy. \$1.00 each.

MII\% RIVIIY. One of the most beautiful lioses. Fine, oval-shaped buds opening to large orange-yellow flowers. Exceedingly free flowering and hardy.

MISS IOLITA MRMOUli. Unique in eoloring, absolutely distinet from any other. Won gold medal in France in 1921 as best novelty Rose. Large, fragrant, full and double flowers with petals of great substanee. Fxpanding they develop a deep coral-red with golden, eoppery-red sucusion, base of petals golden-ye!low with eoppery-red sheen. \$1.00 arch.

MRS. I. IR. WMIMILI, Beautiful pointed buds of rosy-scarlet, opening into extremely showy, large hlooms of coppery-salmon.

HIR. GISO. SIIIITlil. Brilliant rose pink. Large, well-formed blooms, free in growth and hloom.

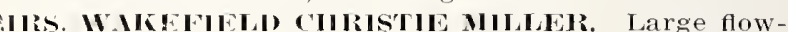
ers of soft, peally linsh, shaded salmon. Outside of petals clear vermilion rose, with lighter shadings.

IIMIIINI, Brilliant, slowing, intense pink.

OPIIELI. Brilliant salmon flesh shaded with ross, with a heart of glowing pcach pink and owange yellow blendings. Fragrant; fuultess in form and eolor. P'IRAIII? Trliciously fragant. Clcar, pure shade of rose pink Beautiful foliage, vely free bloomer A valuable addition to the good roses. \$1.00 each.

RMUINCF, Glorious new Rose, beatiful blendings of carmine rose with opal and eoppery reflections.

(2II) RIIIINCli. sulendid even shade of clear red without a race of any other eolor. large, bold, doulble flowers on heavy ereet stenis, conspieuous even among the choieest kinds.

SINIBCist. Magnificent giant yellow liose, suffused with rrange copper, all intense shades, giving an extremely brilliant efrect. liuds long and pointed.

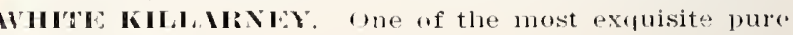
white roses.

MILOMMLIE. A magnitient rich shrimp pink liose, toning to carmine pink toward edges of petals. lieautiful coral red lmds on stout stems, opening into very large, full flowers, \$1.00 each. 
Best Hardy Hybrid Perpetual or June Roses

Irice, 75c each; $\$ 7.00$ per 10.

INXI DE DIESIBACH. Lovely shell pink.

CLIO. (New). Flesh color, center shaded rosy pink.

FRAC KARL DRUSCHK1. (White Mmerican

Beauty.) The ideal pure white Rose

GENERAL JACQUEMIO'. Brilliant scarlet crim-

GoORGE MHRENDS. (Pink Drusehki.) lelicate aink, wonderfully beautiful.

GLOIIE LYONNAISE, Rich, creamy white to pale yellow.

J. B. CLIIK. Intense deep scarlet. Immense size.

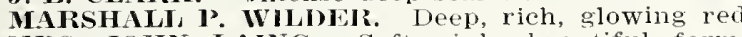
NRS. JOHX LAING. Soft pink, beautiful form fragrant.

PAUI NEYRON. Largcst size; bright, clear, shining

pink. CAMILLE: IDE MOHIN.

erimson, shaded black.

UIRICH BRUNNER. Bright cherry red, large and fu 1

\section{Magnificent New Hardy Climb- ing Roses}

Splendid new sorts of unusual beauty and merit that you will surely want to include in your planting. Climbing Roses can be put to so many good uses that it seems as if every household should have at lcast a few. They are perfectly hardy, requiring comparatively little care after once being planted, and they bear great quantities of lovely flowers.

IVITEU1? BLFRIOT. A magnificent new variet Rich, deep, copper color. Beautiful buds, open ing bloom, borne in great profusion. $60 c$ cach.

CHMBING AMERICAN BHAUTY. Rosy crimson. Same exquisite fragrance as old American Beauty. Hlowers large produced profusely flom spring until frost comes. $75 \mathrm{c}$ cach.

CIIMBING SUNBURST. A true Sunburst Rose of vigorous climbing habit. (See description under Sunburst). \$1.00 each.

DR. W. VAN FLENT. A superb variety. Flowers full and double, of delicate perfume, will run 4 inches and over in diameter when open; buds pointed, flesh pink on outer surface, deepening to rosy flesh in center. $60 \mathrm{c}$ cach.

GNRDENIA. (Harly Marcehal Niel.). An extremely handsome sort of great worth, hardy as ar Oak. Blooms profusely in large, drooping clusters. Double golden yellow flowers that shade to creamy white a few days after they fully expand. boc eiteh.

PIUI'S SCMRLIT CLIMBER. Wonderful new climbing rose Vivid scarlet, making a brilliant display during a long season. Blooms in clusters, strong climbing habit, perfectly hardy \$1 ou each. IRED TAUSENDSCHOLN. (Rosicre.) An improved Tausendschoen, with same habit of growth, but superior in color-a deeper and more even shade of cerise-pink or calmine. A very free bloomer. 756 calch.

SHWFR MOON. Grand new white climbing Rose. Clear, silvery white, with centers a mass o fbright yellow stamens, giving a wonderful contrast. Petals of splendid substance, beautifully cupped. Exceedingly large, fragrant flowers. Vigorous grower and very free blooming. 60c each.

\section{Miscellaneous Hardy Climbing Roses}

\section{DOROTHI PFRIINS. The ouly fragrant Rambler. Shell pink} very double. 50c cach.

IVHTE DOROTIIY PERKINS. 50c each.

ILOWER OF FAIRFIELD (Everblooming Crimson Rambler). 75 each.

IAXCELSA (IRed Dorothy Perkins). Finest of all erimson ramblers. Great quantities of full, double flowers, crimson maroon, tips of petals scarlet. Hardy everywhere. 50c cach.

CRIMSON RAMIBLER. Immense clusters of rich, olowing crimson flowers, that remain for more than two weeks. Goc ach.

TICSWNDSCHOJN . (Thomand Boatien.) Covered with bright blossoms of every shade from white to deep pink, borne in clusters; quite double. 60. each.

\section{Rugosa and Hybrid Rugosa Roses \\ These hardy roses can be used in so many places that they are}

almost indispensable. Sturdy, shrubby bushes, adapted for hedges and hardy borders, or to mix in other shrubbery. Foliage very ornamental, dark, shiny ricl green.

BLANC DE COUBRIT. A splendid double pure white. 75e each. CONIRID F. MiYER. Flowers very large and well filled. Clear silvery rose. Very fragiant. $\mathbf{5}$ c each.

OSA RUgOSA RUBRA. Crimson flowers are iarge and single. followed by glossy red berries. b0c each.

IOSA RUGOSI IIBS. Single white flowers, followed by yellow berries. 75e cach. 


\section{Choice Hardy Perennial Plants}

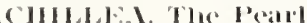

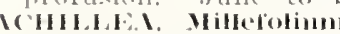

Ivilustis.

INIIISI

(1)

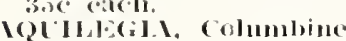

III) IN I lineluells The beauty of the is

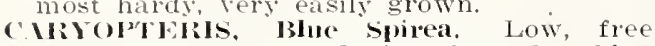
blooming plant producing lavender blue flowers in large, dense cymes from August

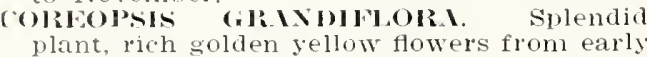
summer until fall.

IIRYsiNTIIIIM. Beautiful plants that when othel plants have been nipped by frost. Colors: White, Yellow, Brown, b.IIsi, sha-tal Large, snowy-white flowers DEIPIIINIUM, Bella DOHIa. (Larkspur.) (ely habit, handIIIPIIXIIN, Formomm. (Larkspur.) white flower's dark blue with bIXxucs. (sweet Willian.) old time farorites, bearing during May and June

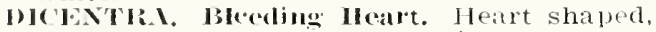
rose-colored fowers in droor
tialy summer. soc all.

IIITIIS. Foxmlove. Had favorite, produc

c Mllallilix, Banlict lower. Large showy

mer to November. minute pure white flowers during June and libilis, Inady candyutut

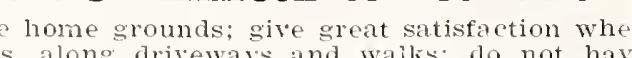

'हा. They are the "old-fashioned" hard. of them should be found in every garden

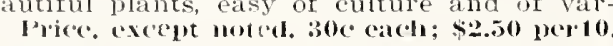
IOJAliocks. louble; Red, Pink, and mbiscis. New Gian sowering. (Mallow Marvels.) Wonderful improved new rar ieties, with richest colors, enomous flow Perfectly hardy. Colors: l'ink, White, and Glimin mis. The true "rleur de Lis," the national flower of France. They are perfectly hardy, thrive anywhere, gow and blossom luxuriantly, palticularly if ed in moist situations, as on the banks of duce from 50 to 100 spikes of bloom. In beauty, the flowers rival the finest orchids, colors langing through richest yellows, intense purples, delicate blues, soft maures, beautiful claret-reds, waite, primJPIN I IS. Finest of all the Iris family. The flowers are of immense sizs, from 6 to 8 inches in diameter, and of the most beau tiful and delicate shades. They are perduring .June and Iuly. A well established plant gives a dozen or more flower stalks 2 to 3 leet high, each stalk producing P.M. II LIR, Oricutal Popry. Showiest of al! poppies, large scarlet and red flowers on

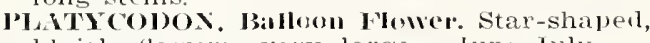
bluish flowers, Iery large. Jun -.July. plant with large flowers of sky blue color.

ThITOM. IRed-hot Poker or Flame Flower. Tall spikes smrmounted by brilliant orange scarlet llower heads. August-September. VEIONICI-subsensilis. 2 feet. July to September. One of the handsomest blue-
fowering plants. Perfectly hardy and flowering plants. Perfectly hardy and Spikes completely studded with beautiful blue flowers; fine for cutting and one of the best plants for the hardy lorder.

P'MRIIIIUM. Sometimes alled sprins Flowering Chrysanthemum. Hardy perennial plant of easy culture, with beautiful, large, daisy-like flowers in a variety of brilliant colors, ranging from intense scarlet to pure white. The flowers are borne on long stems and are splendid for any other flower. The plants have a long

vCCA, Ifan's Neclle. Tropical looking plant with immense, pyramidal clusters of
creamy flowers, fune-July. :35 each.
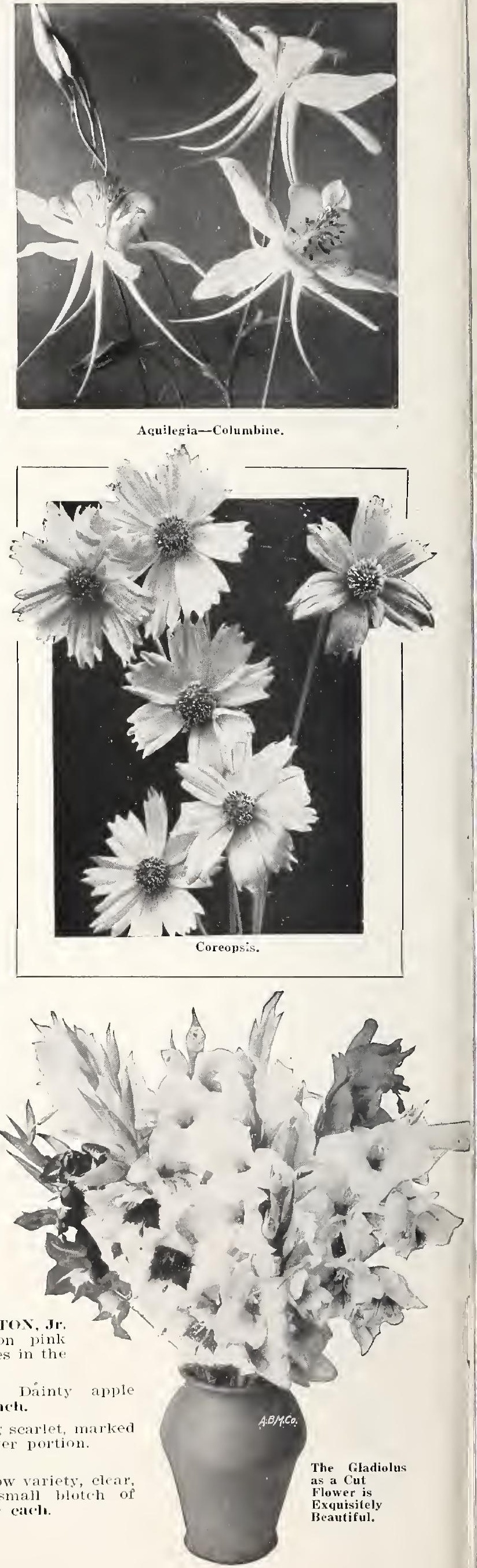


\section{Of Interest to Our Customers}

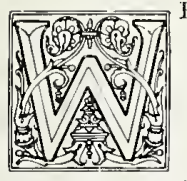

TAKE PLEASURE in sending our latest catalogue and hope you will look it oyer calefully. Yoll will find in it full information about the stork we grow, the hest of the old kinds as well as many nery varieties of merit that have been well tested. We have described our stock fully and honestly. our statements of quality are iust as dircet promises of what we will delver to you as it you were here in our office and we made these statements to you in person. We regard every order as important, and whether

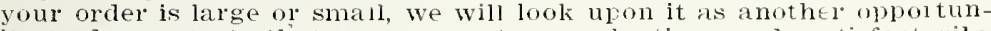
ity to demonstrate that we can meet your planting needs satisfactorily.

QUNLITY. Oui constant aim is to produce trees and plants a nearly perfect as can be grown. And while price is important, quality nearly perfect as can be grown. And while price is important, malicy must always be considered first, as the future growth of your tree
depends largely upon the fuality of the stock you buy. lifery tre plant or shrub we send out are specimens in their class, sure to please the most critical buyer. We offer you the best stock you can buy a prices as low as it is possible to grow and sell this strictly high grade stock. Our stock is dug fresh from the ground in the spring, is packed to reach you in perfect condition. and is backed by our ironclad guarantee of guality and satimfation or money cheelfully re funded.

ORDEIR IARLY. The production of nursery stock was largely curtailed during the war. It takes from 2 to 4 years to produce most kinds of trces and plants, so that on many items there has not leen sufficient time to build up stocks to anythins like normal quantities and there is still a slort smply on many items. Nll indications point to a great revival of planting this coming seanon. It is therefore most important that you aet your order iu early to avoid disappointment. Don't wait until the last minute, but prepare for your planting now. while you have time to think and plan, and send us your order without while yor

TERMS are net easl with order, except where otherwise arranged. SPECIAL DISCOUNT of $5 \%$ allowed on eash orders received before March 15th. $2 \%$ discount on all Cash orders after Malch 15 th. SHIPPING SEASONS. Our spring shipping season opens about the first of April and continues to about May 20th. In the fall we start shipping about October $10 \mathrm{th}$ and continue to about December 1 st.
I'LANTING SEISON is not governed by any particular date or condition of regetation in your section but by the comlition of stock ou arival. Fverything we ship in the spring is dus while still in way winter state, before it has commenced its new searon's orouth. The way we pack for shipment, stock keeps perfectly in this dormant tate until received by you. So that regardless of the condition of regetation in your section when you get our shipment-whether advanced or retarded-thit does not affect our stock in any way, and if you will plant it accolding to directions and give it reasonable care you will nind it will live and thrive.

\section{To Our Canadian Customers}

Nursery stock is admitted from the United States into Canada in the suring, commencing March 15 th and continuing until Nay $15 \mathrm{th}$, and in the fall, commencing September 26 th and continuing until Decem ber 1st. Nursery stock is not admitted through the mails into Canada at any season of the year. so kindly oider shipments made by freight at any season of the year. so kindly order shipments mare
or express. We cannot send by parcel post into Canada.

\section{No Orders for Less than $\$ 1.00$ Accepted}

As it costs us just as much to pack and prepare small orders as it does large ones, and inasmuch as the prices we ask are so close to the actual cost of production, we cannot afford to till orders anount-
ing to less than $\$ 1.00$.

\section{Guarantee}

Wre depend mpon the merit of onr stock of hold and estend ons trade, and every tree, bush or plant is guaranteed up to size specified and strictly A No. 1, healthy thrifty, well rooted, true to name, and free from San Tose Scale or disease of any kind. We use the oreatest precaution to have everything we send out true to name, but if through any fault of ours any stock proves not true to label, we will on proper proof, replace double the number of trees or plants not true, or we will refund the purchase price, plus 6 per cent per annum and also -eplace stock.

\section{We are Members of the American Association of Nurserymen and are on the accredited list of The Northern Nut Growers' Association}

\section{General Planting Directions}

CARE OF STOCK ON MRIRIXIS. All stock should be planted immediately on arrival but if not converient to do
heel roots in ground, covering them thoroughly.

PI. INTING. Dig holes twice the size necessary to take in all the roots; throw out top soil to one side, and use it for filling around the roots; tread the earth hard after planting. The use of water around the roots when filling in the earth depends on the moisture conditions of the ground. If dry, use plenty of water. After planting and during the summer sufficient water should be used to keep the earth moist.

PIRUNING. The limbs of all fruit and ornamental trees, shrubs and roses should be cut back two-thirds when planted. Remove ali surplus branches from trees, leaving, say, three main stems as a basis for head. Always prume to an outside bud, thus insuring outward growth. Peach trees should be pruned to a whip and a head established the second year either high or low as preferred. All roots should be pruned smoothly before planting, cutting off the ends where bruised by digging and shortening others. This is as important as pruning the top.

MULCHING. Mulching is a most necessary factor in successful planting. Cover a space around the tree or shrub to a distance of three feet, using coarse manure, lawn clippings or grass is effective for this purpose if manure cannot be secured. The mulching retains moisture, retards the growth of weeds and facilitates quick growth. When straw or manure is left on the glound all winter, clear a space of 15 inches around the trce to avoid damage from mice.

LABELS. Labels should be removed and some other method adopte

CULTIVATION. Hoe or cultivate frequently. Nothing can thrive if the weeds are allowed to sap the life of the soil.

\section{Special Instructions}

Grape Vines should be planted so that the first bud next to the stem will come on a level with the surfafe of the sround. Grape vines have two layers of roots, from 6 to 8 inches apart, and in planting spread the lower layer of roots in their natural position: fill in the earth and press down in the soil firmly, then spread the sccond layer of roots and fill in the balance of the hole. After planting, trim the vines back to two buds. A strong stick four feet long should be driven in should be planted so as to leave the crown even with the surface. Too deep planting will simother the plant. Nll other small or busl fruits, such as laspberries, currants, wooseberries, ete.. should be planted about one inch deeper than they stood in the nursery, and after plant ing, the tops should be cut back to four or five inches of the ground. In pruning ornamontal trees two-thirds of the top should be cut off on all ornamental trees except cut-leaved birch and horse chestnut, which hould not be pruned at all.

Oruamental slumbs should he planted two inches deeper than they were in the nursery, and the tops cut back one-half. Foss are planted inches alove the

\section{Distances for Planting}

. Standard liars and Strong Growing Cherries. 20 fcet apart each way Duke and Norello Cherrics ............... feet apart each way Standind Plums, Peaches, Apricots, and

\section{Drval'f Pears}

Dwarf Apples

Quinces

to to reet apart each tray

Giapes

10 to 12 feet apart each way

currants and Gooseberries

Raspberies and Blackberries

Strawberies, for Field Culture

Strawberries, for Garden Culture

Asparagus, for Field Culture

10 to 12 feet apart each way Rows 10 feet apart; 7 to 8 feet in rows feet apart 5 to 7 feet

Rule.-Multiply the distance in feet between the rows by the dis tance the plants are apal in the rows, and the product will be the number of square feet in an acre $(43,560)$, will give the number of plants or trees to the acre. 


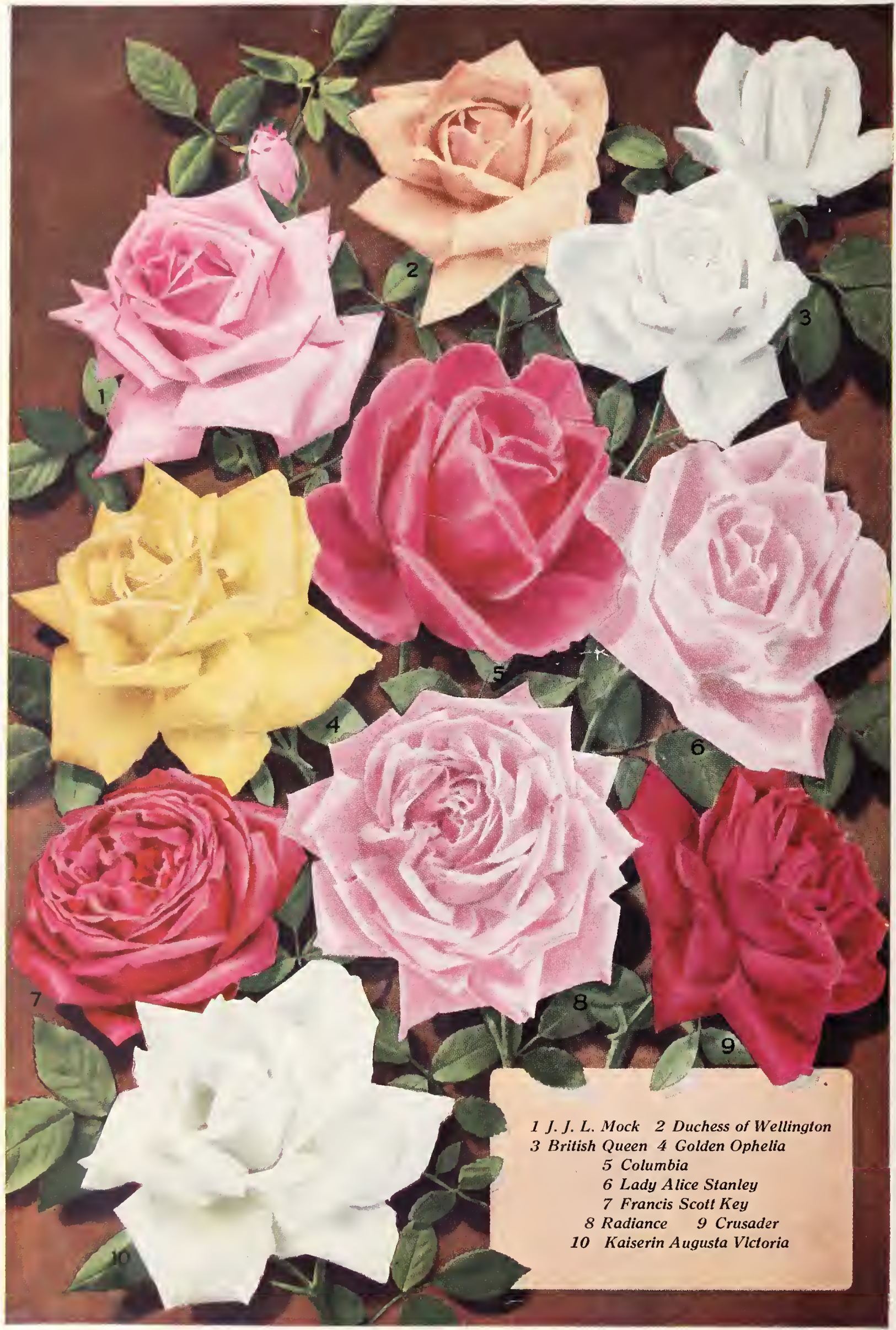

COMPLIMENTS OF

L. W. HALL CO., INC., ROCHESTER, N. Y. 